\title{
MVT-Like Fluorite Deposits and Oligocene Magmatic-Hydrothermal Fluorite-Be-U-Mo-P-V Overprints in Northern Coahuila, Mexico
}

\author{
Antoni Camprubí ${ }^{1, *}$, Eduardo González-Partida ${ }^{2}$, Antonin Richard ${ }^{3}$, Marie-Christine Boiron ${ }^{3}$, \\ Luis E. González-Ruiz ${ }^{4}$, César F. Aguilar-Ramírez ${ }^{5}$, Edith Fuentes-Guzmán ${ }^{5}$, \\ Daniel González-Ruiz ${ }^{4}$ and Claire Legouix ${ }^{3}$ \\ 1 Instituto de Geología, Universidad Nacional Autónoma de México, Ciudad Universitaria, \\ 04510 Coyoacán, Ciudad de México, Mexico \\ 2 Centro de Geociencias, Universidad Nacional Autónoma de México, Boulevard Juriquilla 3001, \\ 76230 Juriquilla, Querétaro, Mexico; egp@geociencias.unam.mx \\ 3 GeoRessourcesLab, Université de Lorraine, Boulevard des Aiguillettes, BP 70239, \\ 54506 Vandœuvre-lès-Nancy, France; antonin.richard@univ-lorraine.fr (A.R.); \\ marie-christine.boiron@univ-lorraine.fr (M.-C.B.); clegouix@osiskomining.com (C.L.) \\ 4 Geologia Minería y Consultoría, S.A. de C.V. Ciprés 104, Frac. Jurica, 76100 Santiago de Querétaro, \\ Querétaro, Mexico; 1_e_g_r@hotmail.com (L.E.G.-R.); edgopa@gmail.com (D.G.-R.) \\ 5 Programa de Posgrado en Ciencias de la Tierra, Universidad Nacional Autónoma de México, \\ Ciudad Universitaria, 04510 Coyoacán, Ciudad de México, Mexico; aguilar.ce.fe@gmail.com (C.F.A.-R.); \\ edithfuentesg@gmail.com (E.F.-G.) \\ * Correspondence: camprubitaga@gmail.com; Tel.: +52-55-5622-4310 (ext. 128)
}

Received: 5 December 2018; Accepted: 11 January 2019; Published: 18 January 2019

Abstract: The formation of most fluorite deposits in northern Coahuila (NE Mexico) is explained by MVT models, and is a part of the metallogenic province of northeastern Mexico. However, fluorite skarn deposits also occur in the same region, and there is evidence for late hydrothermal manifestations with no clear origin and evolution. The latter are the main focus of this study; in particular, F-Be-U-Mo-V-P stringers in the Aguachile-Cuatro Palmas area that overprint preexisting fluorite mantos. The region experienced the emplacement of several intrusives during the Eocene and the Oligocene that are collectively grouped into the East Mexico Alkaline Province (EMAP) and postdate MVT-like deposits. Some of these intrusives have associated skarn deposits; most of them are polymetallic, but the unusual El Pilote deposit contains fluorite mineralisation that was remobilised from MVT-like deposits. The formation of the Aguachile deposit (and, collectively, part of the Cuatro Palmas deposit) has been attributed to a shallow retrograde skarn model. The Cuatro Palmas and Las Alicias fluorite deposits consist of MVT-like deposits overprinted by late hydrothermal fluorite mineralisation rich in Be-U-Mo-V-P, and the Aguachile deposit consists entirely of the latter type. The systematic fluid inclusion study of MVT-like, skarn, and late hydrothermal fluorite deposits reveals a very different distribution of temperature and salinity data that allows the discrimination of mineralising fluids for the type of deposit. MVT-like deposits were formed by fluids with temperatures of homogenisation that range between $50{ }^{\circ} \mathrm{C}$ and $152{ }^{\circ} \mathrm{C}$ and salinities between 5 and $15.5 \mathrm{wt} . \% \mathrm{NaCl}$ equivalent. The El Pilote fluorite skarn was formed by fluids with temperatures of homogenisation that range between $78{ }^{\circ} \mathrm{C}$ and $394{ }^{\circ} \mathrm{C}$ and salinities between 5 and $34 \mathrm{wt} . \% \mathrm{NaCl}$ equivalent, and include $\mathrm{CaCl}_{2}$-rich brines with salinities that range between 24.5 and $29.1 \mathrm{wt}$.\% $\mathrm{CaCl}_{2}$. Late shallow fluorite-Be-U-Mo-V-P hydrothermal deposits were formed by fluids with temperatures of homogenisation that range between $70{ }^{\circ} \mathrm{C}$ and $180{ }^{\circ} \mathrm{C}$ and salinities between 0.9 and $3.4 \mathrm{wt} . \% \mathrm{NaCl}$ equivalent; the sole exception to the above is the La Fácil deposit, with salinities that range between 7.9 and $8.8 \mathrm{wt} . \% \mathrm{NaCl}$ equivalent. While temperatures of homogenisation are similar between MVT-like and late hydrothermal deposits, and both even 
have hydrocarbon-rich fluid inclusion associations, the salinity of late deposits is similar to that of retrograde skarn fluids, although further diluted. However, homogenisation temperatures tend to be higher in late hydrothermal than in MVT-like deposits, thus making them more similar to retrograde skarn fluids. Although this characteristic cannot solely establish a genetic link between a retrograde skarn model and late hydrothermal deposits in the study area, the characteristics of fluids associated with the latter separate these deposits from those ascribed to an MVT-like model. Assuming that mineralising fluids for late fluorite-Be-U-Mo-V-P hydrothermal deposits may correspond to a retrograde skarn (or "epithermal") deposit, the source for fluorine may be either from (A) the dissolution of earlier formed MVT-like deposits, (B) the entrainment of remaining F-rich basinal brines, or (C) hydrothermal fluids exsolved from highly evolved magmas. Possibilities A and B are feasible due to a hypothetical situation similar to the El Pilote skarn, and due to the occurrence of hydrocarbon-rich fluid inclusions at the La Fácil deposit. Possibility $\mathrm{C}$ is feasible because intrusive bodies related to highly evolved magmas would have provided other highly lithophile elements like $\mathrm{Be}, \mathrm{U}$ and Mo upon the exsolution of their hydrothermal fluids. Such intrusive bodies occur in both study areas, and are particularly conspicuous at the Aguachile collapse structure.

Keywords: fluorite; beryllium; uranium; molybdenum; hydrothermal; MVT; retrograde; skarn; Coahuila; Mexico

\section{Introduction}

The Aguachile mining district (Figure 1) lies northwest of Melchor Múzquiz in the northernmost part of the state of Coahuila (northeastern Mexico). It occurs in the Mexican Fold and Thrust Belt, on the border between the Burro-Peyotes Paleopeninsula (or Platform) and the Sabinas Basin, that were two of the most prominent paleogeographic features in the region during the Mesozoic (see Figure 2 in [1]). Many Mississippi Valley Type (MVT; Pb-Zn) and associated (fluorite, celestine and barite) deposits occur in this region, thus making up the MVT Province of Northeastern Mexico altogether, and are distributed in preferential mineralised areas that are described as subprovinces, along with $\mathrm{Cu}-\mathrm{Co}-\mathrm{Zn}$ and $U$ red bed-hosted deposits [1-4]. The Aguachile distict and neighbouring areas contain a variety of fluorite deposits that encompass different deposit types. The Aguachile deposit comprises a ring dyke hosted by Mesozoic limestones that developed a fluorite-Be mineralisation around the dyke, and a syenite intrusion in a central position, which are described as a collapse structure [5,6]. These intrusions are part of the alkaline magmatism in the Eastern Mexican Alkaline Province (EMAP; dated Late Eocene to Present; see references in [3]), that correlates with the pre-Oligocene Trans-Pecos belt in Texas [7,8]. In association with the Aguachile collapse structure, a dyke swarm intrudes several previously-formed MVT fluorite deposits [1,2,9-12] that are hosted by the same carbonate rock sequences. Some of the MVT-like fluorite deposits in the region contain localised uranium-rich mineral associations, which historically precluded mining for fluorite. The La Fácil (within the dominantly MVT Cuatro Palmas deposit) and Las Alicias deposits are the best exposed examples of such mineralisation.

During the Eocene, a cluster of hydrothermal U deposits [3] and references therein formed in association with rhyolitic magmatism in Chihuahua (over $300 \mathrm{~km}$ west of Aguachile). Evidence for post-intrusion hydrothermal uranium deposits has been reported for Texas and Coahuila as well [13]. Although (a) these deposits do not strictly belong to the Trans-Pecos trend towards the Eastern Mexican Alkaline Province or EMAP, (b) the associated volcanism has not been ascribed to the EMAP, neither genetically/chemically nor geographically, and (c) no genetic link between them and the small U-rich fluorite deposits in Coahuila has been defined, they are a consistent evidence of hydrothermal activity that resulted in the formation $U$ deposits in northeastern Mexico. Thus, it may be metallogenically relevant for both the Chihuahuan and Coahuilan $\mathrm{U}$ deposits to explore their possible common ancestry in order to contribute to the ill-defined metallogeny of the EMAP [3]. 

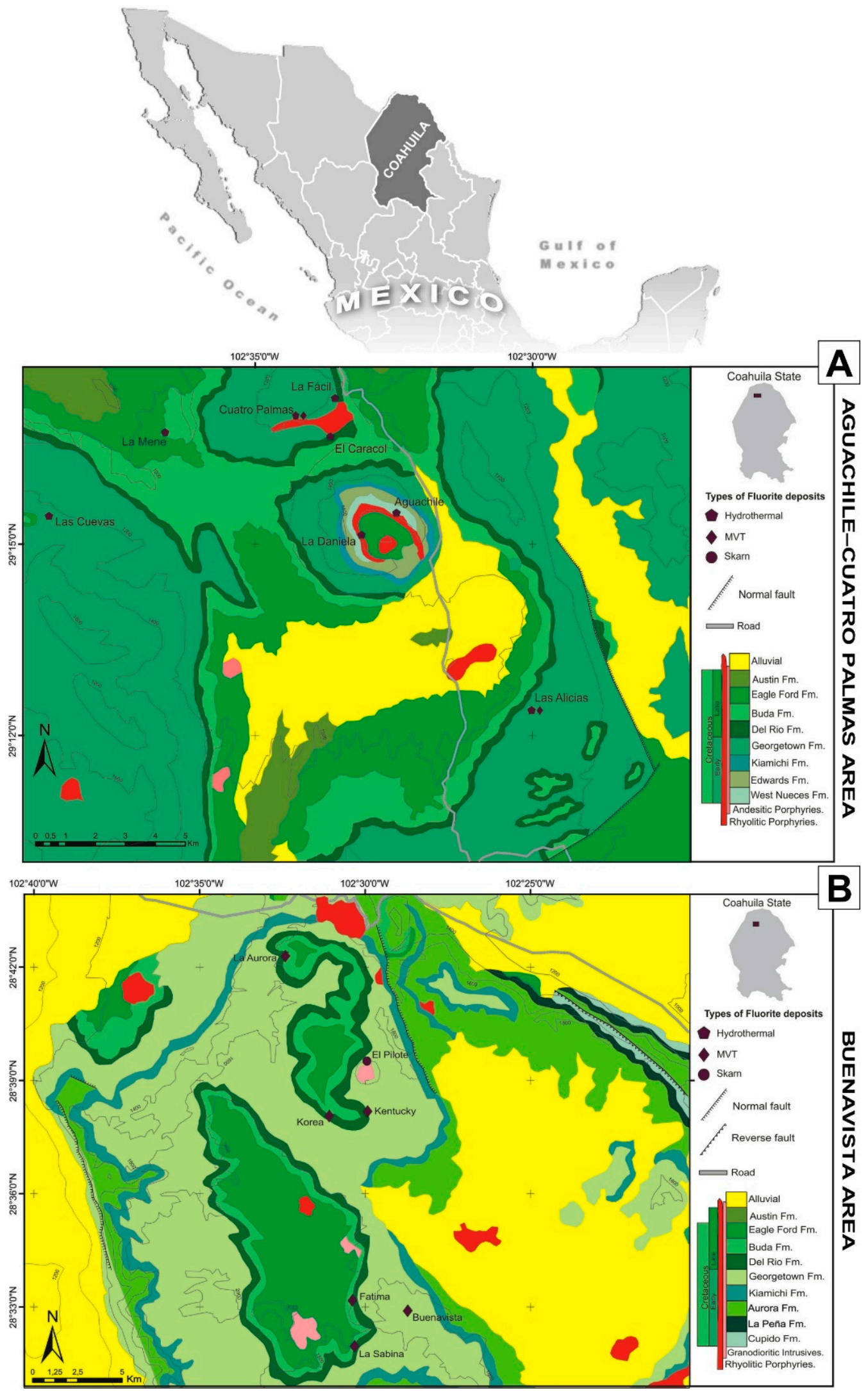

Figure 1. Local geology of the two study areas that include three different types of fluorite mineralisation in northernmost Coahuila: (A) the Aguachile-Cuatro Palmas area, and (B) the Buenavista area. 
Another possibility is that MVT mineralising fluids were somehow endowed in $U$ and that $U$ minerals precipitated along with fluorite at some late stage of mineralisation. As mentioned above, there are several $U$ deposits in siliciclastic formations in the region. The formation of such deposits is attributed to similar fluids to those that formed MVT and associated deposits, and about the same time [1,2]. Besides U-rich associations, Be-rich associations that similarly postdate MVT-like deposits, occur in the study area.

As both the alkaline volcanogenic and MVT scenarios are reasonable to explain the formation of late U-bearing mineral associations to fluorite deposits, this paper aims to characterise the mineralogy and the mineralising fluids of the La Fácil and Las Alicias deposits. However, Be-rich associations are unlikely in MVT and other sedimentary-diagenetic environments. Such an effort comprises both the early MVT fluorite mineralisation and the late U- and Be-bearing mineralisation.

\section{Regional Geology}

The regional stratigraphy of Coahuila and neighboring states has been summarised by $[1,2]$ and references therein. It consists of continental to deep marine sedimentary rocks that formed during the Mesozoic in the peripheral basins in the northeastern corner of the Paleo-Gulf of Mexico after the breakup of Pangea. A platform depositional environment developed on the Burro-Peyotes Paleopeninsula (BPP) since the Early-Middle Albian transgression. In the broad, low-relief and slowly subsiding platform that resulted, a thick sequence of micritic carbonates with flint nodules and abundant planctonic foraminifera deposited. The Upper Tamaulipas Formation was deposited in the basin and the Aurora Formation (southern Coahuila), the Cuchillo Formation (Chihuahua), and the Atascosa and Glen Rose Formations (southern Texas and northern Coahuila) were deposited on the surrounding platforms [14]. These formations are the oldest in the study area. The BPP is part of the Coahuilan fold belt at the northernmost portion of the Sierra Madre Oriental [15], where deformation developed as wide and symmetrical NNW-striking folds. The Aguachile and Cuatro Palmas area is found in this region, on the border between the BPP and the Sabinas Basin [16].

During the Late Cretaceous, mostly detritic sediments were deposited, although oscillating depositional patterns in the basin and on the platforms resulted in thinly bedded carbonates, marls and shales; these are the West Nueces, Edwards, Mc Knight, Salmon Peak, Del Río, Buda, Eagle Ford, Austin, Upson, Boquillas, and San Vicente Formations. These formations altogether are over $600 \mathrm{~m}$ thick [16] and constitute the main outcrops in the Aguachile area. The limestones of the Aurora or Glen Rose Formations are conformably overlain by a sequence of shales and clay-rich limestones interbedded with thinly bedded shaly limestones of the West Nueces Formation. The Edwards Formation was continuously deposited and consists of a carbonate sequence of thickly-bedded and massive limestones with interbedded calcareous shales. The overlying McKnight Formation consists of interbedded shales and clay-rich limestones, and the Salmon Peak Formation consists of thickly bedded massive limestones with abundant rudists and caprinids. The contact between the latter and its overlying and underlying formations is concordant and abrupt. The Salmon Peak Formation is overlain by the Del Río Formation, that consists basically of shales with some interbedded clay-rich limestones and limolites. The Buda Formation overlies the latter concordantly, albeit abruptly, and contains thinly- to thickly-bedded mudstones with pelagic fossils. The Eagle Ford Formation contains abundant clays as alternating shales and clay-rich limestones, and occasional sandy horizons. It is overlain by the Coniacian to Santonian Austin Formation, that consists of clay-rich limestones with some calcareous shales. The Mesozoic sequences end with massive beds of dark gray calcareous shales with interbedded shales of the Upson Formation, and limestones of the Boquillas and San Vicente formations.

The Mesozoic sequence is visibly intruded by plutonic or hypabyssal rocks that range compositionally from granite to syenite $[5,6]$ of the Eastern Mexican Alkaline Province (EMAP). Volcanic breccias and pyroclastic flows are often associated with rhyolitic porphyries as at the Pico Etéreo ("Ethereal Peak") $[5,6,17,18]$. Several andesitic and ryolitic porphyry dyke arrays are common. 
Such Eocene to Oligocene southward-younging magmatism (44.6 to $30 \mathrm{Ma}$ in northern Coahuila; see references in [3]) is oriented NW-SE and was considered part of the Trans-Pecos province by [19]. The piston-like gravitational collapse that occurred at Aguachile was "welded" by a rhyolitic ring dyke, and there is a syenite intrusion in the middle of the downthrown block which is associated with late resurgence. This suggests that the ring dyke is older than the syenite intrusion, and the fluorite-Be deposits are associated with the ring dyke, whereas no mineralisation is associated with the syenite. Several peripheral dykes are seemingly suturing a larger oval structure around the Aguachile mine, and crosscut the preexisting Las Alicias (a few km south of Aguachile) and La Fácil (north of Aguachile, in the Cuatro Palmas mine) MVT-like fluorite orebodies.

\section{Mineral Deposits of the Region}

Mineral deposits in northern Coahuila are dominated by MVT-like fluorite deposits, but the region also contains significant magmatic-hydrothermal ore deposits in association with the East Mexico Alkaline Province (EMAP), which correspond mostly to the skarn type [3]. The vast majority of skarns have associated retrograde polymetallic sulfide-rich deposits, with the exception of the El Pilote and Aguachile deposits. The latter case, however, remains uncertain in terms of its type of deposit, despite being generally acknowledged as part of the skarn "family" [3] and references therein. El Pilote, a small 28.4 Ma fluorite deposit in the La Encantada-Buenavista area, has an undisputed skarn origin that owes its fluorite content to remobilised mineralisation from previously existing MVT-like mantos [20,21]. Such deposits include the neighbouring Buenavista deposit, the second largest fluorite deposit in Mexico and one of the largest in the world [9], and the adjacent Korea and Aurora deposits (Figure 1). No other skarns in this region are entirely constituted by fluorite, although it remains as a conspicuous mineral, as in the La Encantada polymetallic skarn [22]. Also, the La Vasca skarn deposit contains peripheral fluorite mineralisation along with Ag and base metals [23,24], and the La Morena skarn and associated epithermal deposits consist of base metals with scarce fluorite [25]. In the latter cases, the likelihood of fluorite being derived from the remobilisation of pre-existing MVT-like deposits is yet to be evaluated.

The mineral deposits in the Aguachile-Cuatro Palmas area are mostly hosted by limestones of the Del Río Formation (Figures 1 and 2) and are found at a distance of up to $100 \mathrm{~km}$ north of the La Babia fault zone [1,3]. The vast majority of Mississippi Valley-type deposits (MVT) in northern Coahuila are made up of fluorite (most notably, Buenavista), some are essentially celestine deposits, and in others (e. g., El Tule) both minerals appear to be equally abundant. Red bed-hosted metallic deposits are relatively scarce along the La Babia fault zone, in contrast to their abundance within the Sabinas basin and the Chihuahua trough, and near the San Marcos fault zone, on the southern border of the Sabinas basin $[1,3,4]$. Both MVT-like and red bed-hosted deposits in the area were interpreted to have formed from basinal brines that were multiepisodically squeezed out through the La Babia and San Marcos fault zones (and other minor structures to a lesser extent) due to lithostatic pressure and the Laramide/Sevier orogenic compression, and reached favorable layers for stratabound mineralisation at different levels in the stratigraphic column [1]. Although MVT mineralisations in Northeastern Mexico lack any radiochronometric data, cross-cutting relationships suggest that they normally predate Eocene to Oligocene skarns and hydrothermal veins associated with the magmatism of the EMAP. The following deposits attest to the magmatic-hydrothermal Eocene to Oligocene metallogeny in northern Coahuila: (A) host intrusives to the La Vasca skarn deposits yielded an ${ }^{40} \mathrm{Ar} /{ }^{39} \mathrm{Ar}$ age of 44.59 Ma [26], (B) host intrusives to the La Morena skarn and epithermal deposits yielded an ${ }^{40} \mathrm{Ar} /{ }^{39} \mathrm{Ar}$ age of 32.17 Ma [27], (C) host intrusives to the Aguachile fluorite-Be deposit were dated at $33 \mathrm{Ma}$ (undisclosed method [28]), (D) host intrusives to the Mina Fronteriza Ag-Au-base metal deposits (possibly epithermal) yielded a K-Ar age of $39 \mathrm{Ma}$ [29], (E) host intrusive to the El Pilote fluorite skarn was dated at 28.4 Ma (U/Pb [21]), and (F) sphalerite in the Pb-Zn(-Ga) Tres Marías deposit was dated at $28.8 \pm 1.7 \mathrm{Ma}$ (Rb-Sr [30]), although no direct evidence of magmatism was found in the latter. Cenozoic magmatism in the area is associated with the EMAP [3] and youngs southwards. 
The northernmost portion of the province, besides skarn and epithermal deposits, includes several magmatic-hydrothermal iron-oxide deposits in western Coauhuila and eastern Chihuahua, plus uranium vein deposits and rare-element carbonatites in northern Chihuahua [3] and references therein. The metallogeny of the EMAP is poorly constrained and needs much attention on critical aspects like (A) the petrologic evolution within local magmatic centers as well as regionally, (B) the role of regional-scale faults in focusing the emplacement of magmatic-hydrothermal ore deposits, (C) the genesis of the several types of deposits that are associated with its magmatism, (D) the nature of such association, (E) the regional extent of the different types of deposits, and (F) the overprinting of different types of deposits, particularly those that were associated with the same (whether cryptic or not) structural corridors, among other geologic features.

Then, the specific origin of some hydrothermal deposits in the study region may be found in either "family" of mineral deposits, that is, among those of the magmatic-hydrothermal or sedimentary-diagenetic types. Such is the dilemma for U-rich deposits that, in northern Mexico, are found in both families as Au-U veins associated with felsic magmatism (and placers derived from these) or as red-bed hosted deposits [3] and references therein.

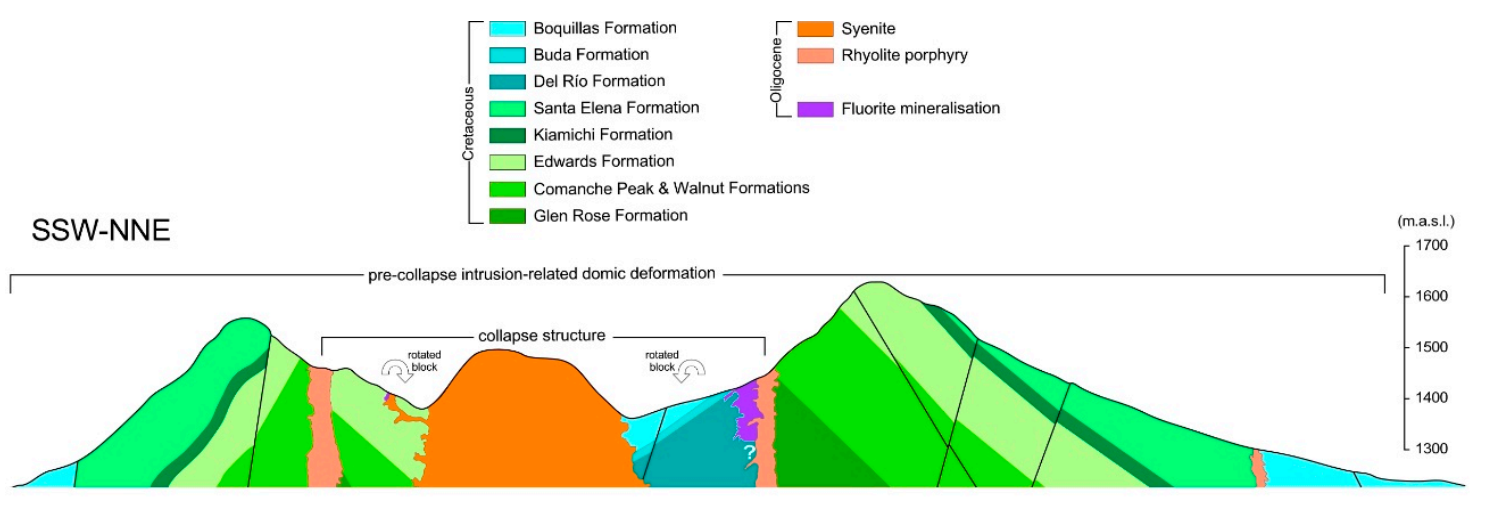

Figure 2. Representative cross-section of the Aguachile deposit, Coahuila. Adapted from [5]. No vertical exaggeration.

\section{Mineralogy}

\subsection{MVT-like Fluorite Deposits}

Much alike most fluorite deposits in the northernmost part of the MVT province of Northeastern Mexico [1-3,31], the studied deposits are essentially monomineralic, with the exception of variable amounts of quartz, calcite and dolomite. In the Cuatro Palmas deposits (El Caracol and La Fácil mines) the MVT-like fluorite mineralisation occurs as mantos and breccias. The upper part of the mineralised mantos show roof brecciation that suggests hydrothermal karstification (Figure 3A); brecciation also includes already formed fluorite mineralisation (Figure 3B). Several kinds and sizes of botryoidal textures and rhythmites are the most common type of arrangement, particularly those that developed as "zebra" textures (Figure 4A). Vugs lined by colourless to purplish euhedral fluorite crystals are common (Figure 4A,B). Among botryoidal textures, there are conspicuous brecciated stalactitic structures (Figure 4B,C). Fluorite mantos and breccias were crosscut by hypabyssal intrusives (Figure 3C) that are attributed to the Oligocene calc-alkaline to alkaline magmatism of the EMAP province. Botryoidal textures can be observed at the Las Alicias mine as well, where honey-brown skeletal fluorite crystals may form botryoids that can attain over $1 \mathrm{~m}$ in diameter (Figure 4D); these are similar to those described in the Las Cuevas mine in San Luis Potosí [32]. Several brecciation stages can be found, and late fluorite + calcite veins or calcite lining vugs represent the last apparent evidence for MVT-like mineralisation. 

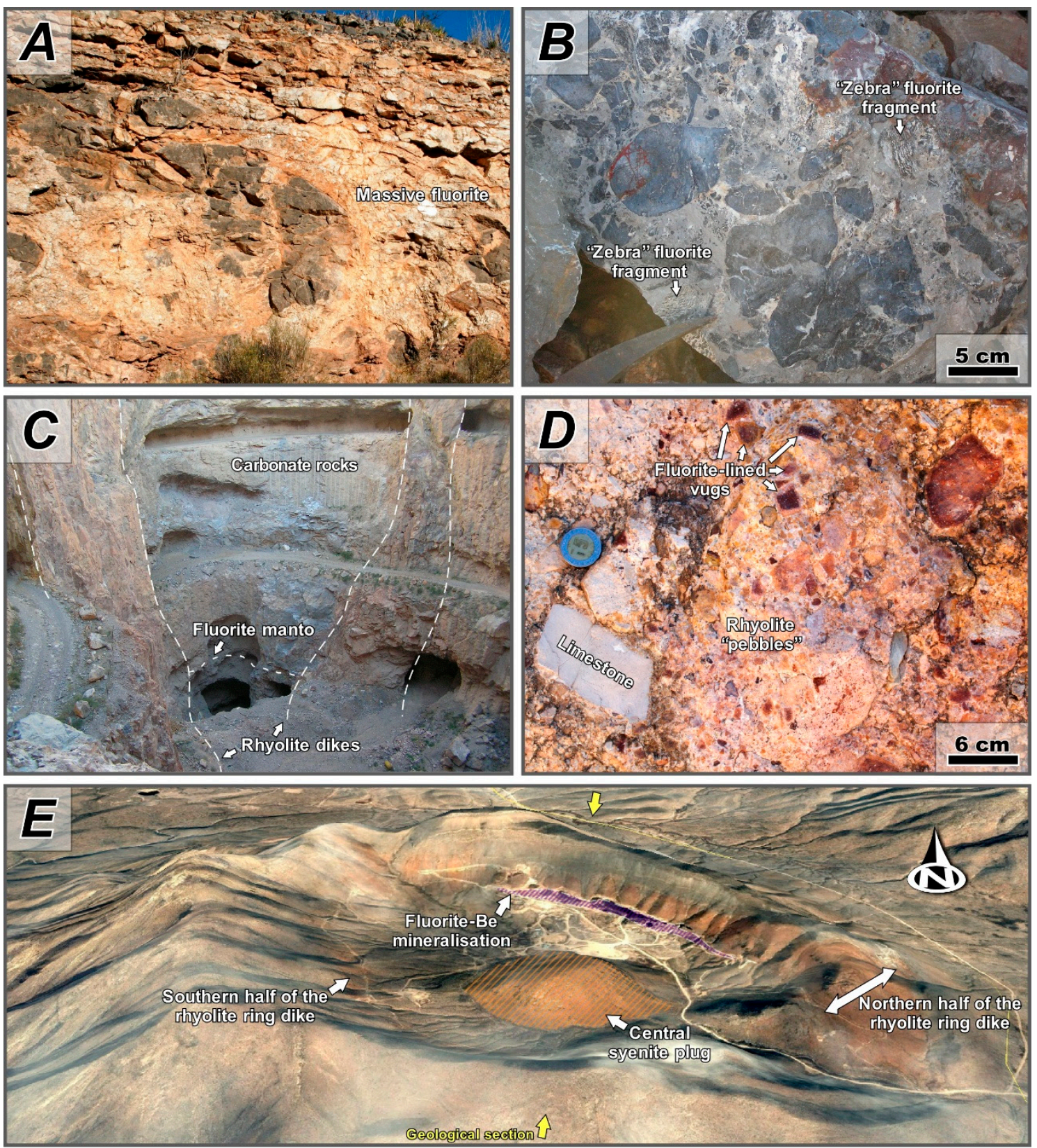

Figure 3. Macroscopic traits of MVT-like fluorite and later fluorite-U-V-Mo-P mineralisation in the Aguachile-Cuatro Palmas area, Coahuila. (A) Pendant roof breccia in the upper part of the MVT-like massive and partly banded fluorite mineralisation at the La Fácil deposit. (B) Late structural/hydrothermal breccia with host limestones ans zebra-like MVT fluorite mineralisation as fragments at the El Caracol deposit. (C) Eocene rhyolite dikes crosscutting MVT-like stratabound fluorite mantos at the El Caracol deposit. (D) Pebbly facies on the mineralised shoulder of the northern half of the rhyolite ring dike at the Aguachile deposit; notice the occurrence of purplish fluorite lining cavities. (E) Google Earth image of the relief in the Aguachile deposit and its intrusive complex, as of January 2018. 

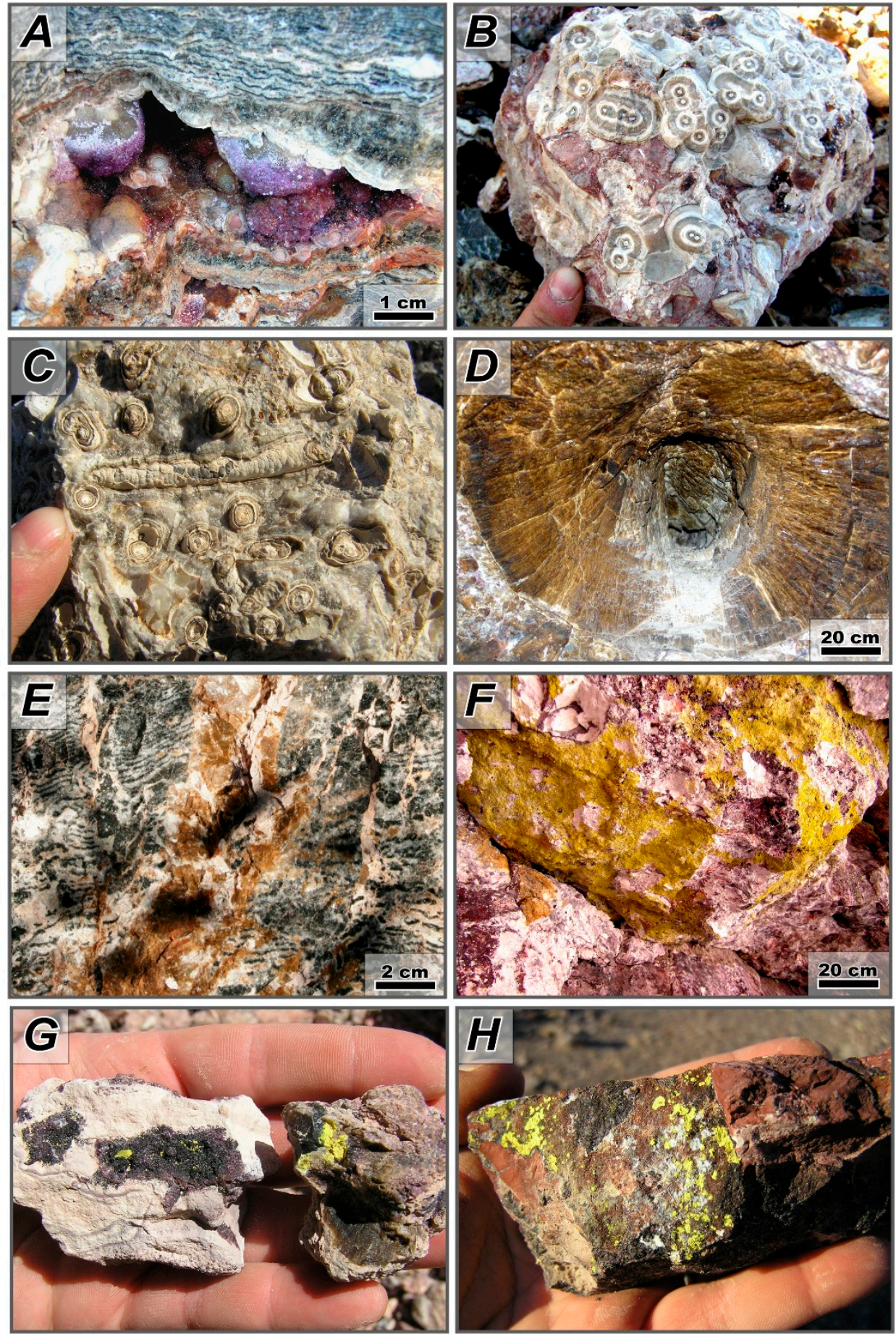

Figure 4. Macroscopic arrangement of MVT-like fluorite (A-E) and later fluorite-U-V-Mo-P mineralisation (F-H) in the Aguachile-Cuatro Palmas area, Coahuila. (A) Zebra-like fluorite mineralisation and purplish euhedral fluorite lining cavities; La Fácil deposit. (B,C) Stalactitic growths of pure fluorite, brecciated and cemented by later fluorite; La Fácil deposit. (D) Large skeletal fluorite crystals in botryoidal arrangements, eventually affected by later brecciation; Las Alicias deposit. (E) MVT-like zebra fluorite crosscut by later hydrothermal brown fluorite and calcite; El Caracol mine. (F) Yellow carnotite-lined fractures within earlier MVT-like brecciated fluorite and host sedimentary rocks; Las Alicias deposit. (G) Hand specimens of stringers within host sedimentary rocks showing the early fluorite+carnotite association in them; Las Alicias deposit. (H) Hand specimen of carnotite (yellow) stringers with abundant crandallite needle-like crystals with a radial arrangement (white); Las Alicias deposit. 


\subsection{Fluorite-Be-U-Mo-P-V Associations}

MVT-like mineralised bodies are systematically overprinted in the study area by hypogene hydrothermal Be-rich or U-rich fluorite mineralisation, mostly as veinlets and stringers. In addition, small fluorite skarn-related mineralisation can be found as remobilisations of pre-existing MVT-like fluorite bodies; such is the case of the El Pilote skarn [20,21] next to the large MVT-like fluorite deposits at Buenavista, $\sim 60 \mathrm{~km}$ south of the study area. Hydrothermal associations postdate the same Oligocene hypabyssal rocks that crosscut MVT-like fluorite mineralisation, as stated above. Be-rich mineralisation (0.1 to $0.3 \% \mathrm{BeO}$ [33]) is found in the Aguachile, La Daniela and Las Alicias mines, where mineralisation consists of fluorite, bertrandite $\left[\mathrm{Be}_{4} \mathrm{Si}_{2} \mathrm{O}_{7}(\mathrm{OH})_{2}\right]$, calcite, quartz, hematite, iron oxihydroxides, aragonite, adularia, powellite $\left[\mathrm{CaMoO}_{4}\right]$, gypsum and illite [6,34]. Such mineralisation is found as relatively irregular $450 \mathrm{~m}$ long and up to $140 \mathrm{~m}$ thick masses (thinning and pinching out with depth) whose emplacement was controlled by the south contact of the northern half of the rhyolite ring dike in the Aguachile mine (Figure 3E,D), whereas at Las Alicias, it occurs solely as veinlets or stringers hosted by MVT-like fluorite mineralisation (Figure 4E-H). There is evidence in the Aguachile mine that points to some enrichment in $\mathrm{Zn}-\mathrm{Pb}-\mathrm{Cu}-\mathrm{Ag}$ [18] that would agree better with a "typical" retrograde skarn mineralisation than the known associations for this area, or even REE mineralisation [33].

Fluorite-Be-U-Mo-P-V veinlets are preferentially hosted by breccias that affect MVT-like fluorite mineralisation in the Las Alicias mine, and were also developed as veinlets or stringers. Fluorite in such deposits is generally deep purple (Figure $5 \mathrm{~A}, \mathrm{E}, \mathrm{F}$ ) and visible associated carnotite (Figure 3E,H and Figure 5B,F). Carnotite also occurs along calcite in altered hypabyssal rocks where kaolinite and sericite are additional hydrothermal alteration minerals (Figure 5C,D). Autoradiographies were obtained for the selected samples, which included fluorite in MVT-like as well as later veinlets, and showed that $U$ is virtually absent anywhere in the samples except in the latter (Figure 5F). The mineralogy of fluorite-U-V-Mo-P veinlets consists of early fluorite, gypsum, quartz, kaolinite, and crandallite $\left[\mathrm{CaAl}_{3}\left(\mathrm{PO}_{4}\right)_{2}(\mathrm{OH})_{5} \cdot\left(\mathrm{H}_{2} \mathrm{O}\right)\right]$, and late carnotite $\left[\mathrm{K}_{2}\left(\mathrm{UO}_{2}\right)_{2} \mathrm{~V}_{2} \mathrm{O}_{8} \cdot 3 \mathrm{H}_{2} \mathrm{O}\right]$, iron oxihydroxides and powellite (Figure 5E-D). Fluorite and carnotite are closely associated, although it is likely that carnotite formed reactively upon fluorite (Figure 6B) after acidic fluids with which kaolinite was stable (Figure 6A). In such associations, $\mathrm{pH}$ of 3 to 5 and Eh of +0.2 to -0.1 were determined [33]. The systematic high potassium content in the analysed vanadates suggests that the dominant $\mathrm{U}$ mineral is carnotite, although the occurrence of tyuyamunite $\left[\mathrm{Ca}\left(\mathrm{UO}_{2}\right)_{2} \mathrm{~V}_{2} \mathrm{O}_{8} \cdot 5-8 \mathrm{H}_{2} \mathrm{O}\right]$ cannot be ruled out, provided that other minerals in these associations are also Ca-rich (fluorite, crandallite, powellite, gypsum, calcite). Fluorite of MVT-like assemblages, as well as quartz and gypsum from late veinlets, show evidence of having experienced dissolution at some stage (Figure 6D-F). Such features, and the early gypsum-quartz-kaolinite association, an argillic assemblage, suggest the incursion of acidic hydrothermal fluids during the formation of fluorite-U-V-Mo-P veinlets. Kaolinite, quartz and gypsum occur as automorphic crystals (Figure 6), up to $\sim 20 \mu \mathrm{m}, \sim 100 \mu \mathrm{m}$ and $\sim 200 \mu \mathrm{m}$ across, respectively. Crandallite is found in vugs as $\sim 50 \mu \mathrm{m}$ to $\mathrm{cm}$-sized long thin prismatic to baguette-like crystals (Figure 6C). Carnotite occurs generally as groundmasses of micron-sized (eventually up to $100 \mu \mathrm{m}$ in diameter; Figure 6A) platy crystals in book-like arrangements (Figure 6B), or as crustiform aggregates. Oxihydroxides occur as botryoidal crusty aggregates or groundmasses in vugs and along crystal boundaries (Figures $5 \mathrm{E}$ and $6 \mathrm{~F}-\mathrm{H}$ ). Powellite occurs as up to $\sim 10 \mu \mathrm{m}$ across euhedral dipyramidal crystals (Figure $6 \mathrm{H}$ ). Despite the close association in space between fluorite and the rest of minerals, the precipitation of fluorite clearly occurred earlier than the rest of minerals, with virtually no visible coprecititation (Figure 7). 

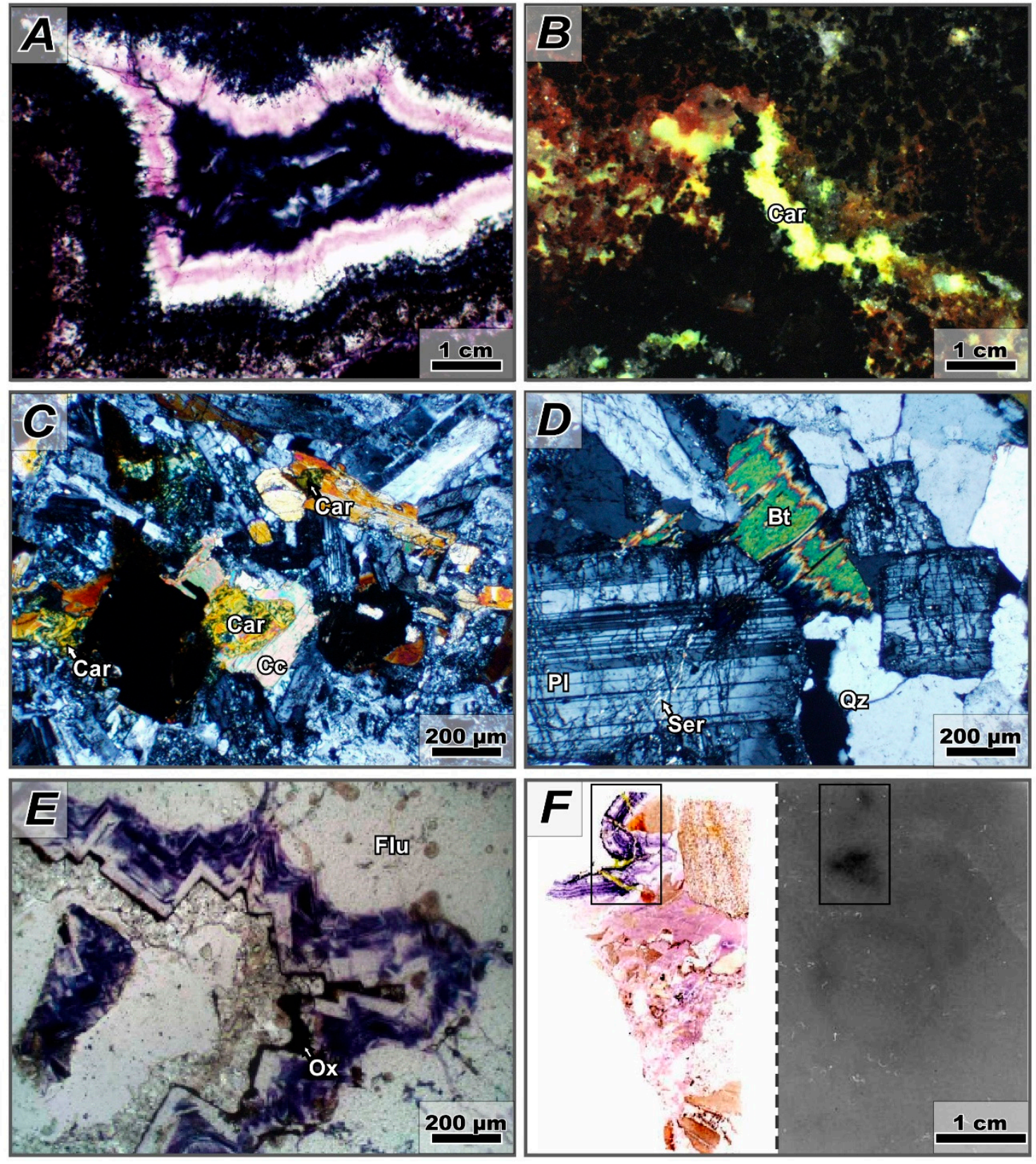

Figure 5. Photomicrographies of thin sections from the U-rich fluorite deposits in the Aguachile area, Coahuila. All images with parallel polars unless otherwise noted. (A) Colloform banding as vug lining in late fluorite in MVT-like mineralisation. (B) Late stringers with carnotite (yellow) and iron oxihydroxides (reddish). (C) Carnotite and calcite replacing magmatic minerals in an Oligocene hypabyssal rhyodacite near the Las Alicias area. (D) Incipient sericitic alteration in a granitic porphyry near the Las Alicias area. (E) Purplish to colourless euhedral lining of fractures as overgrowths on MVT-like fluorite (colourless) followed by iron oxihydroxides and V-Mo-P mineralisation with little U. (F) Thin section of a MVT-like fluorite breccia crossed by a late fluorite-U-V-Mo-P stringer (encased within a rectangle) with its self-radiography on the right-hand side; notice the change in colour of fluorite from the MVT-like associations (light purple to pink) to the late hydrothermal stringers (deep purple), which include yellow carnotite. Key: $\mathrm{Bt}=$ biotite, $\mathrm{Car}=$ carnotite, $\mathrm{Cc}=$ calcite, Flu = fluorite, $\mathrm{Ox}=$ iron oxihydroxides, $\mathrm{Pl}=$ plagioclase, $\mathrm{Qz}=$ quartz, $\mathrm{Ser}=$ "sericite". 

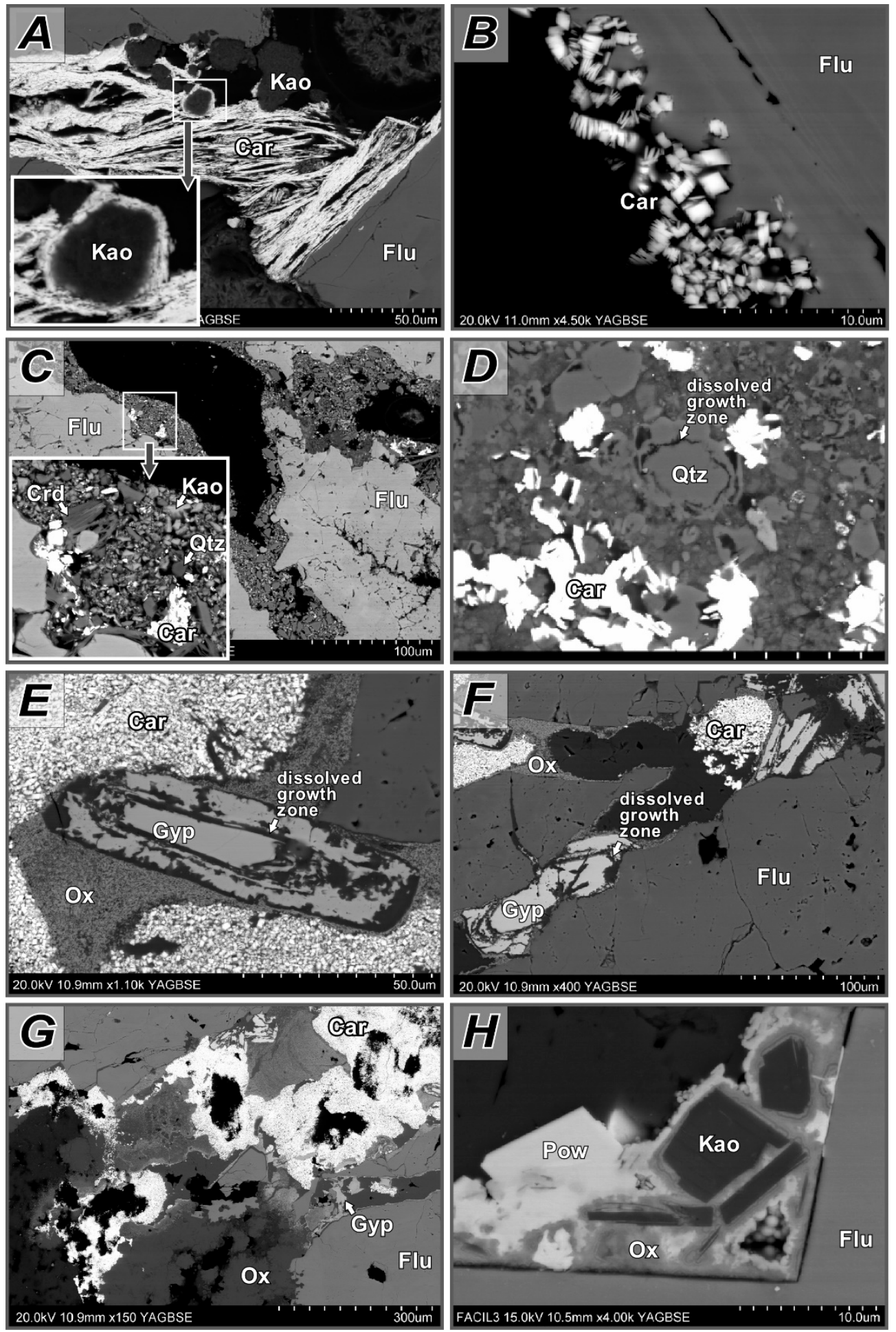

Figure 6. Back-sacattered electron images of mineral associations in the fluorite-U-V-Mo-P stringers in the Aguachile area, Coahuila. (A) Kaolinite "lumps" enveloped by carnotite crystals in fractures in MVT-like fluorite. (B) Carnotite crystal aggregates intergrown with fluorite in the early parageneses. (C) Association that consists of carnotite, crandallite, kaolinite and quartz. (D) Quartz with dissolved growth zones in association with carnotite. (E,F) Early carnotite and late iron oxihydroxides with partially dissolved gypsum. (G) General aspect of stringers with early carnotite and late iron oxihydroxides. (H) Late mineralisation with kaolinite, iron oxihydroxides and powellite on fluorite. Key: $\mathrm{Car}=$ carnotite, $\mathrm{Crd}=$ crandallite, $\mathrm{Flu}=$ fluorite, $\mathrm{Gyp}=$ gypsum, $\mathrm{Kao}=$ kaolinite, $\mathrm{Ox}=$ iron oxihydroxides, Pow = powellite, $\mathrm{Qtz}=$ quartz. 


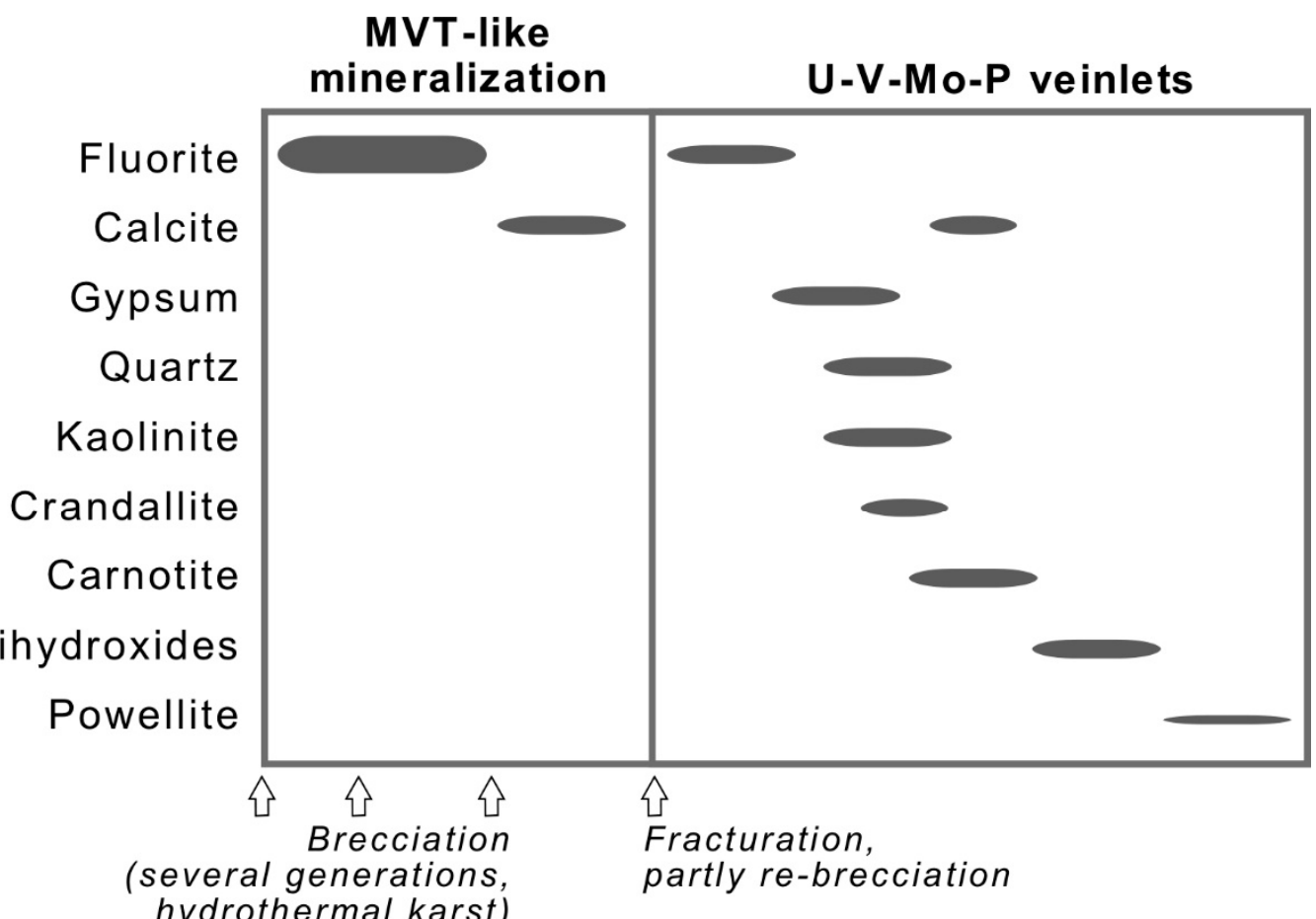

Figure 7. General paragenetic chart for the MVT-like fluorite and later fluorite-U-V-Mo-P mineralisation in the Aguachile-Cuatro Palmas area, Coahuila (based on the La Fácil and Las Alicias deposits).

\section{Fluid Inclusions}

Fluid inclusion petrographic and microthermometric studies were carried out in 38 representative samples, comprising both fluorite from MVT-like fluorite and late hydrothermal fluorite-Be or fluorite-U deposits from the Aguachile-Cuatro Palmas area. Additionally, for comparison purposes, we also analysed representative samples from the El Pilote fluorite skarn. The studied samples were doubly polished sections (100 to $150 \mu \mathrm{m}$ thick). Primary, pseudosecondary and secondary inclusions were found, but, for this paper, only primary and pseudosecondary inclusions were used. The analysed inclusions for MVT-like and late hydrothermal deposits are liquid-rich (their degree of filling, or $F$, is $>0.90$; Figure 8), contain no daughter crystals, and their sizes range from 5 to $150 \mu \mathrm{m}$. The analysed inclusions for the El Pilote skarn are also liquid-rich ( $F$ ranges between 0.75 and 0.90 ; Figure 9$)$, and may contain halite or sylvite daughter crystals; there are also dolomite and wollastonite trapped crystals, plus at least three non-identified phases. Some daughter crystals appear as "elongated" halite crystals. As some of the fluid inclusion associations in the El Pilote skarn account for $\mathrm{CaCl}_{2}$-dominated brines (instead of $\mathrm{NaCl}$ ), it is possible that such crystals belong, in fact, to some orthorhombic or pseudocubic calcium chloride (i.e., sinjarite $\left[\mathrm{CaCl}_{2} \cdot 2 \mathrm{H}_{2} \mathrm{O}\right]$ or chlorocalcite $\left[\mathrm{KCaCl}_{3}\right]$ ). Many inclusions in MVT-like and late hydrothermal fluorite deposits contain both aqueous liquids and liquid hydrocarbons in variable ratios in the absence of post-trapping changes, thus pointing to heterogeneous trapping from inmiscible liquids. Some fluid inclusion associations in the El Pilote skarn show inclusions with variable $F$ with no evidence for any post-trapping phenomena, which may account for their heterogeneous trapping under boiling conditions.

Primary fluid inclusions occur in growth zones parallel to crystal faces, or occur as solitary inclusions or isolated groups of inclusions lacking healed fractures (in cases in which growth zones could not be identified). Growth zones in fluorite, as evidenced by changes in colour, were seldom identified; in most cases, fluorite was colourless or its colour distribution was patchy or uneven. Pseudosecondary inclusions occur along fractures that were covered by later growth zones. Several primary and pseudosecondary inclusions showed evidence of necking, stretching or leakage. Necking after liquid contraction is manifested in groups of fluid inclusions that resulted in a wide range of 
vapor to liquid ratios (degree of filling). These have relatively irregular shapes, distinct from stair-like shapes that are typical for fluorite, with elongated terminations that point to similar terminations in other inclusions. All fluid inclusions homogenised into liquid phases. Microthermometric studies were carried out on a Linkam THMSG600 heating-freezing stage. Calibration runs show that the measurements are accurate to $\pm 0.2{ }^{\circ} \mathrm{C}$ for low-temperature measurements, and to $\pm 2{ }^{\circ} \mathrm{C}$ for high-temperature measurements. Salinities were calculated by using freezing point depression temperatures for fluid inclusions with no daughter crystals and halite solubilisation temperatures of daughter crystals in the SALTY software and the state equations by [35,36]. The obtained microthermometric data are displayed in Table 1 and Figure 10.

Inclusion fluids in fluorite deposits in the Aguachile-Cuatro Palmas and the Buenavista areas can be described by means of the following data ranges:

- Fluid inclusions in MVT-like deposits show temperatures of homogenisation (Th) that range between $50{ }^{\circ} \mathrm{C}$ and $152{ }^{\circ} \mathrm{C}$ and temperatures of ice melting (Tmi) that range between $-4{ }^{\circ} \mathrm{C}$ and $-11.5^{\circ} \mathrm{C}$, which correspond to calculated salinities between 5 and $15.5 \mathrm{wt} . \% \mathrm{NaCl}$ equivalent. Such data are distributed among individual deposits as follows:

(a) In the Buenavista deposit, Th range between $50{ }^{\circ} \mathrm{C}$ and $152{ }^{\circ} \mathrm{C}$, Tmi range between $-4{ }^{\circ} \mathrm{C}$ and $-11.5^{\circ} \mathrm{C}$, and salinities range between 5 and $15.5 \mathrm{wt} . \% \mathrm{NaCl}$ equivalent.

(b) In the La Aurora deposit, Th range between $80^{\circ} \mathrm{C}$ and $146^{\circ} \mathrm{C}$, Tmi range between $-5.5^{\circ} \mathrm{C}$ and $-10.4{ }^{\circ} \mathrm{C}$, and salinities range between 8.6 and $14.4 \mathrm{wt} . \% \mathrm{NaCl}$ equivalent.

(c) In the Korea deposit, Th range between $114{ }^{\circ} \mathrm{C}$ and $140{ }^{\circ} \mathrm{C}$, Tmi range between $-8.2{ }^{\circ} \mathrm{C}$ and $-11^{\circ} \mathrm{C}$, and salinities range between 11.8 and $15 \mathrm{wt} . \% \mathrm{NaCl}$ equivalent.

- Fluid inclusions in late fluorite-Be-U-Mo-V-P hydrothermal deposits show temperatures of homogenisation (Th) that range between $70^{\circ} \mathrm{C}$ and $180^{\circ} \mathrm{C}$ and temperatures of ice melting (Tmi) that range between $-0.5^{\circ} \mathrm{C}$ and $-5.7^{\circ} \mathrm{C}$, which correspond to calculated salinities between 0.9 and $8.8 \mathrm{wt} . \% \mathrm{NaCl}$ equivalent. Such data are distributed among individual deposits as follows:

(a) In the Daniela deposit, $\mathrm{Th}$ range between $136{ }^{\circ} \mathrm{C}$ and $165{ }^{\circ} \mathrm{C}$, Tmi range between $-2{ }^{\circ} \mathrm{C}$ and $-2.1^{\circ} \mathrm{C}$, and salinities range between 3.4 and $3.6 \mathrm{wt} . \% \mathrm{NaCl}$ equivalent.

(b) In the Aguachile deposit, Th range between $134{ }^{\circ} \mathrm{C}$ and $172{ }^{\circ} \mathrm{C}$, Tmi range between $-1.9^{\circ} \mathrm{C}$ and $-2.1^{\circ} \mathrm{C}$, and salinities range between 3.2 and $3.4 \mathrm{wt} . \% \mathrm{NaCl}$ equivalent.

(c) In the Cuatro Palmas deposit, Th range between $98{ }^{\circ} \mathrm{C}$ and $180{ }^{\circ} \mathrm{C}$, Tmi range between $-0.2{ }^{\circ} \mathrm{C}$ and $-0.9{ }^{\circ} \mathrm{C}$, and salinities range between 0.4 and $1.6 \mathrm{wt} . \% \mathrm{NaCl}$ equivalent.

(d) In the La Fácil deposit, Th range between $86^{\circ} \mathrm{C}$ and $140{ }^{\circ} \mathrm{C}$, Tmi range between $-5^{\circ} \mathrm{C}$ and $-5.7^{\circ} \mathrm{C}$, and salinities range between 7.9 and $8.8 \mathrm{wt} . \% \mathrm{NaCl}$ equivalent.

(e) In the Las Alicias deposit, Th range between $70^{\circ} \mathrm{C}$ and $128^{\circ} \mathrm{C}$, Tmi range between $-0.5^{\circ} \mathrm{C}$ and $-1{ }^{\circ} \mathrm{C}$, and salinities range between 0.9 and $1.7 \mathrm{wt} . \% \mathrm{NaCl}$ equivalent.

- Fluid inclusions in the El Pilote fluorite skarn show temperatures of homogenisation $(T h)$ that range between $78{ }^{\circ} \mathrm{C}$ and $394{ }^{\circ} \mathrm{C}$. Temperatures of ice melting (Tmi) range between $-3^{\circ} \mathrm{C}$ and $-11.5^{\circ} \mathrm{C}$ for $\mathrm{NaCl}-$ dominated inclusion fluids with no daughter crystals, which correspond to calculated salinities between 5 and $15.5 \mathrm{wt} . \% \mathrm{NaCl}$ equivalent. Temperatures of halite solubilisation (Ts) range between $180^{\circ} \mathrm{C}$ and $230^{\circ} \mathrm{C}$ for NaCl-dominated inclusion fluids with daughter halite crystals, which correspond to salinities between 30 and $34 \mathrm{wt} . \% \mathrm{NaCl}$. Tmi range between $-27^{\circ} \mathrm{C}$ and $-42{ }^{\circ} \mathrm{C}$ for $\mathrm{CaCl}_{2}$-dominated inclusion fluids with no daughter crystals, which correspond to calculated salinities between 24.5 and $29.1 \mathrm{wt} . \% \mathrm{CaCl}_{2}$. 
Table 1. Summary of fluid inclusion data from hydrothermal fluorite-Be-U-Mo-P-V deposits in the Aguachile-Cuatro Palmas area and from other types of fluorite deposits (for comparison) in northern Coahuila state, NE Mexico.

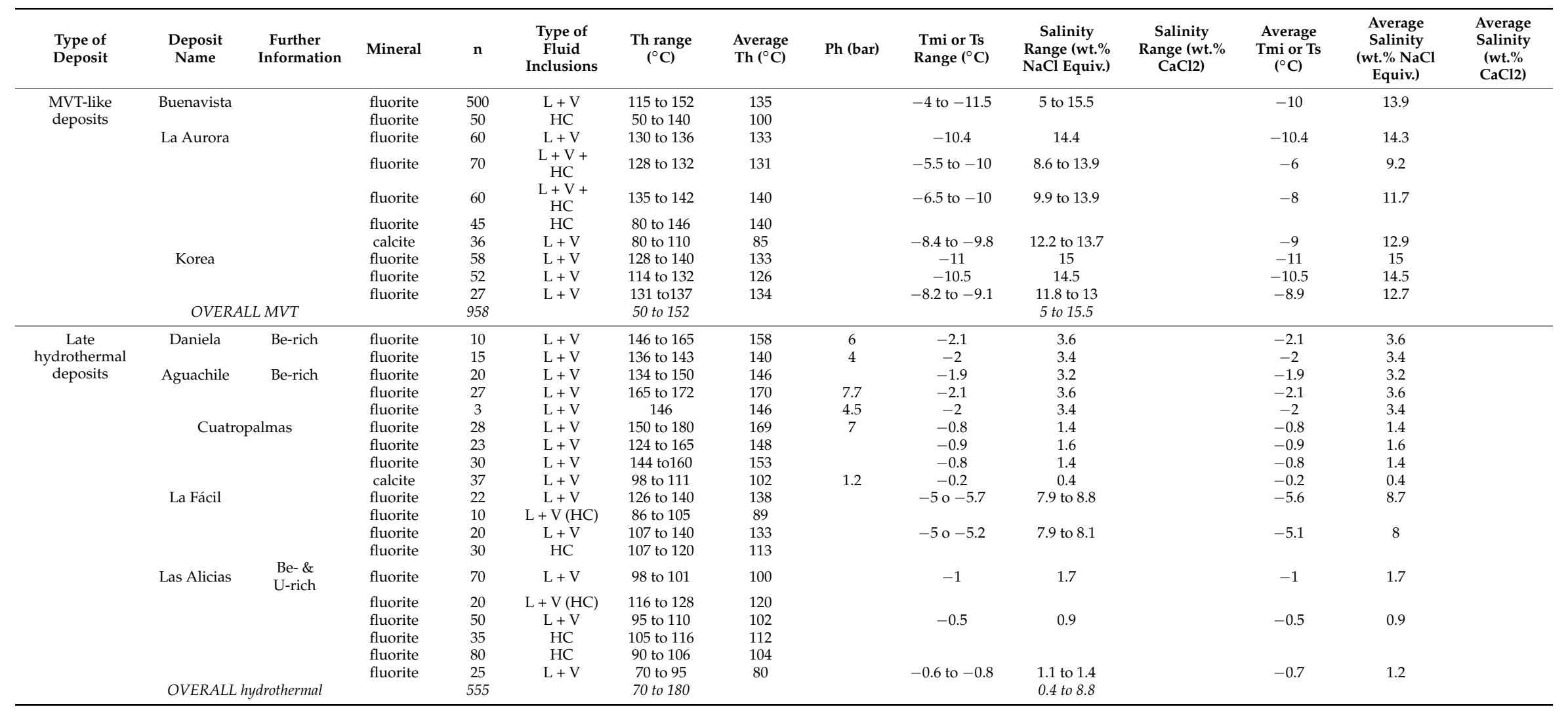


Table 1. Cont.

\begin{tabular}{|c|c|c|c|c|c|c|c|c|c|c|c|c|c|c|}
\hline $\begin{array}{l}\text { Type of } \\
\text { Deposit }\end{array}$ & $\begin{array}{l}\text { Deposit } \\
\text { Name }\end{array}$ & $\begin{array}{l}\text { Further } \\
\text { Information }\end{array}$ & Mineral & $\mathbf{n}$ & $\begin{array}{l}\text { Type of } \\
\text { Fluid } \\
\text { Inclusions }\end{array}$ & $\begin{array}{c}\text { Th range } \\
\left({ }^{\circ} \mathrm{C}\right)\end{array}$ & $\begin{array}{l}\text { Average } \\
\text { Th }\left({ }^{\circ} \mathrm{C}\right)\end{array}$ & Ph (bar) & $\begin{array}{c}\text { Tmi or Ts } \\
\text { Range }\left({ }^{\circ} \mathrm{C}\right)\end{array}$ & $\begin{array}{c}\text { Salinity } \\
\text { Range (wt.\% } \\
\text { NaCl Equiv.) }\end{array}$ & $\begin{array}{c}\text { Salinity } \\
\text { Range (wt. } \% \\
\text { CaCl2) }\end{array}$ & $\begin{array}{c}\text { Average } \\
\text { Tmi or Ts } \\
\left({ }^{\circ} \mathrm{C}\right)\end{array}$ & $\begin{array}{c}\text { Average } \\
\text { Salinity } \\
\text { (wt.\% NaCl } \\
\text { Equiv.) }\end{array}$ & $\begin{array}{c}\text { Average } \\
\text { Salinity } \\
\text { (wt.\% } \\
\text { CaCl2) }\end{array}$ \\
\hline \multirow{10}{*}{ Fluorite skarn } & \multirow[t]{10}{*}{ El Pilote } & $\begin{array}{l}\text { late } \\
\text { loinlot }\end{array}$ & fluorite \& & 29 & $\mathrm{~L}+\mathrm{V}$ & 80 to 98 & 90 & 0.8 & -3 to -6 & 5 to 9.2 & & -4 & 6.5 & \multirow{10}{*}{$\begin{array}{l}24.8 \\
26.5 \\
25.2\end{array}$} \\
\hline & & stockwork & fluorite & 38 & $\mathrm{~L}+\mathrm{V}$ & 177 to 182 & 180 & 9 & -10 to -11.5 & 13.9 to 15.5 & \multirow{4}{*}{24.8 to 26} & -10.5 & 14.5 & \\
\hline & & stratabound & fluorite & 33 & $L+V^{*}$ & 116 to 121 & 119 & & -28 to -31 & & & -30 & & \\
\hline & & stratabound & fluorite & $\begin{array}{l}50 \\
50\end{array}$ & $\mathrm{~L}+\mathrm{V}$ & 179 to 182 & 181 & 8.7 & -10 to -11.5 & 13.9 to 15.5 & & -10.8 & 14.8 & \\
\hline & & stratabound & fluorite & 45 & $\mathrm{~L}+\mathrm{V}$ & 126 to 129 & 128 & 3.6 & -2.2 to -6 & 3.7 to 9.2 & & -5.7 & 8.8 & \\
\hline & & stratabound & fluorite & 51 & $L+V^{*}$ & 115 to 117 & 116 & & -27 to -29 & & 24.5 to 25.2 & -28 & & \\
\hline & & $\begin{array}{l}\text { stratabound } \\
\text { stabo }\end{array}$ & calcite & 60 & $\mathrm{~L}+\mathrm{V}^{*}$ & 78 to 105 & 95 & & -31 to -34 & & 26 to 26.9 & $\begin{array}{l}-20 \\
-33\end{array}$ & & \\
\hline & & skarn & garnet & 4 & $\mathrm{~L}+\mathrm{V}^{*}$ & 380 to 394 & 387 & 205 & -28 to -42 & & 24.8 to 29.1 & -29 & & \\
\hline & & skarn & calcite & 40 & $\mathrm{~L}+\mathrm{V}+\mathrm{S}$ & 200 to 250 & 240 & 33 & 180 to 230 & 30 to 34 & & 220 & 32 & \\
\hline & & OVERALL skarn & & 350 & & 78 to 394 & & & & 3.7 to 34 & 24.8 to 29.1 & & & \\
\hline
\end{tabular}

Key: HC = hydrocarbons, MVT = Mississippi Valley-type deposits, $\mathrm{n}=$ number of analysed inclusions, $\mathrm{Ph}=$ pressure of homogenisation, $\mathrm{S}=$ daughter crystal (halite), Th = temperature of

homogenisation, $\mathrm{Tmi}=$ temperature of ice melting, $\mathrm{Ts}=$ temperature of solubilisation of daughter halite crystals, $\mathrm{V}=$ water vapour, $\mathrm{V}(\mathrm{HC})=$ vapour hydrocarbons. Note: Asterisks ${ }^{*}$ ) in the last column denote the occurrence of calcic brines. in which $\mathrm{CaCl} 2$ dominates over $\mathrm{NaCl}$ as the main solute species. 

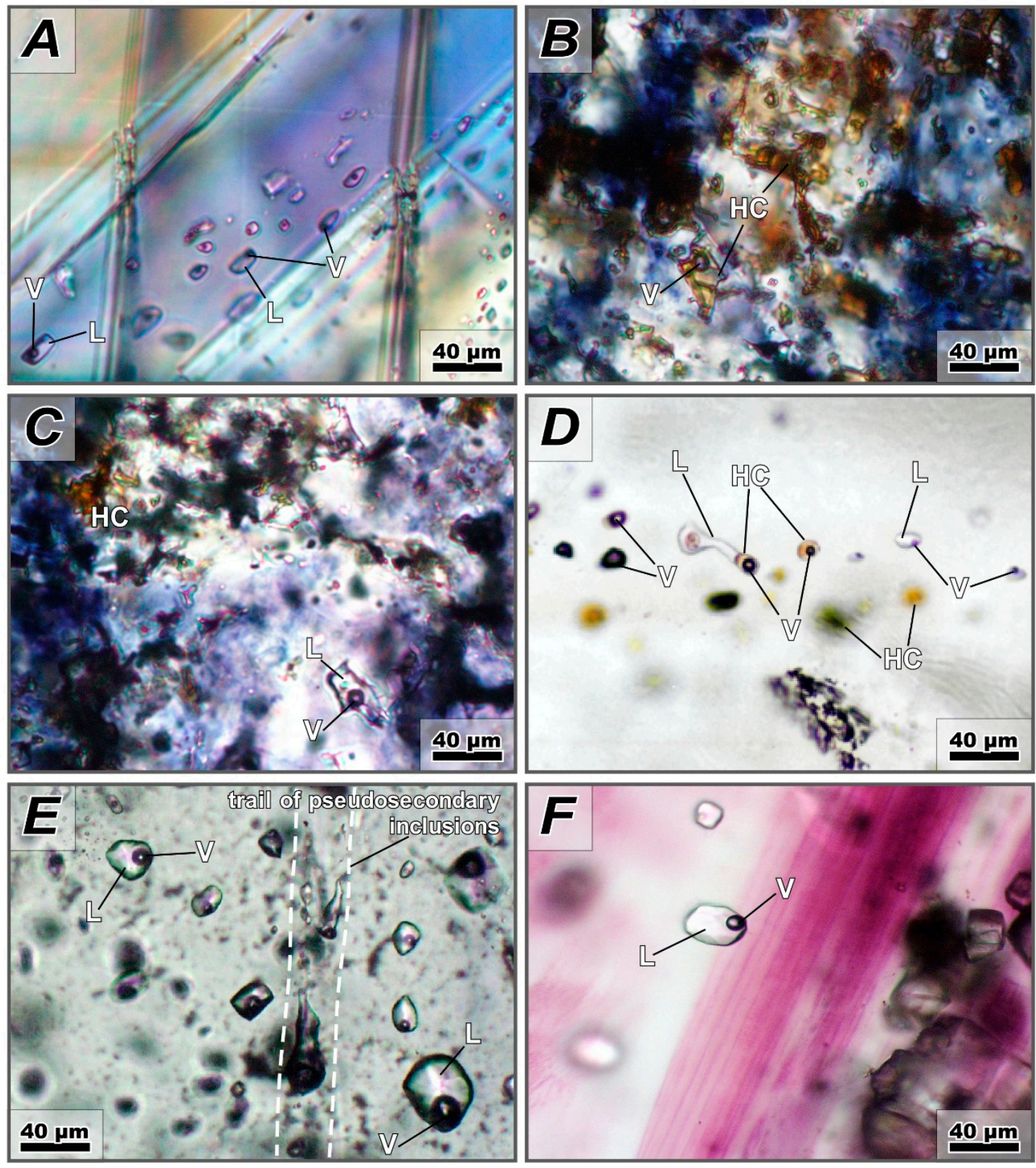

Figure 8. Photomicrographs of the analysed fluid inclusions for MVT-like (A to C) and late hydrothermal fluorite deposits ( $\mathbf{D}$ to $\mathbf{F}$ ) in the Aguachile area, Coahuila. (A) Pseudosecondary two-phase liquid-rich aqueous inclusions in purplish fluorite. (B to D) Primary inclusions in fluid inclusion assemblages that attest to heterogeneous trapping of hydrocarbon (yellowish to brown) and aqueous liquids, in purple (MVT-like) to colourless (late hydrothermal) fluorite. (E,F) Primary fluid inclusions in late hydrothermal fluorite, as isolated groups crossed by pseudosecondary inclusions (E) or following crystal zoning marked by changes in colour (F). Notice the variability in the relative volume that hydrocarbons and aqueous fluids occupy in individual inclusions. Key: HC = liquid hydrocarbon, $\mathrm{L}=$ aqueous liquid, $\mathrm{V}=$ vapour. 


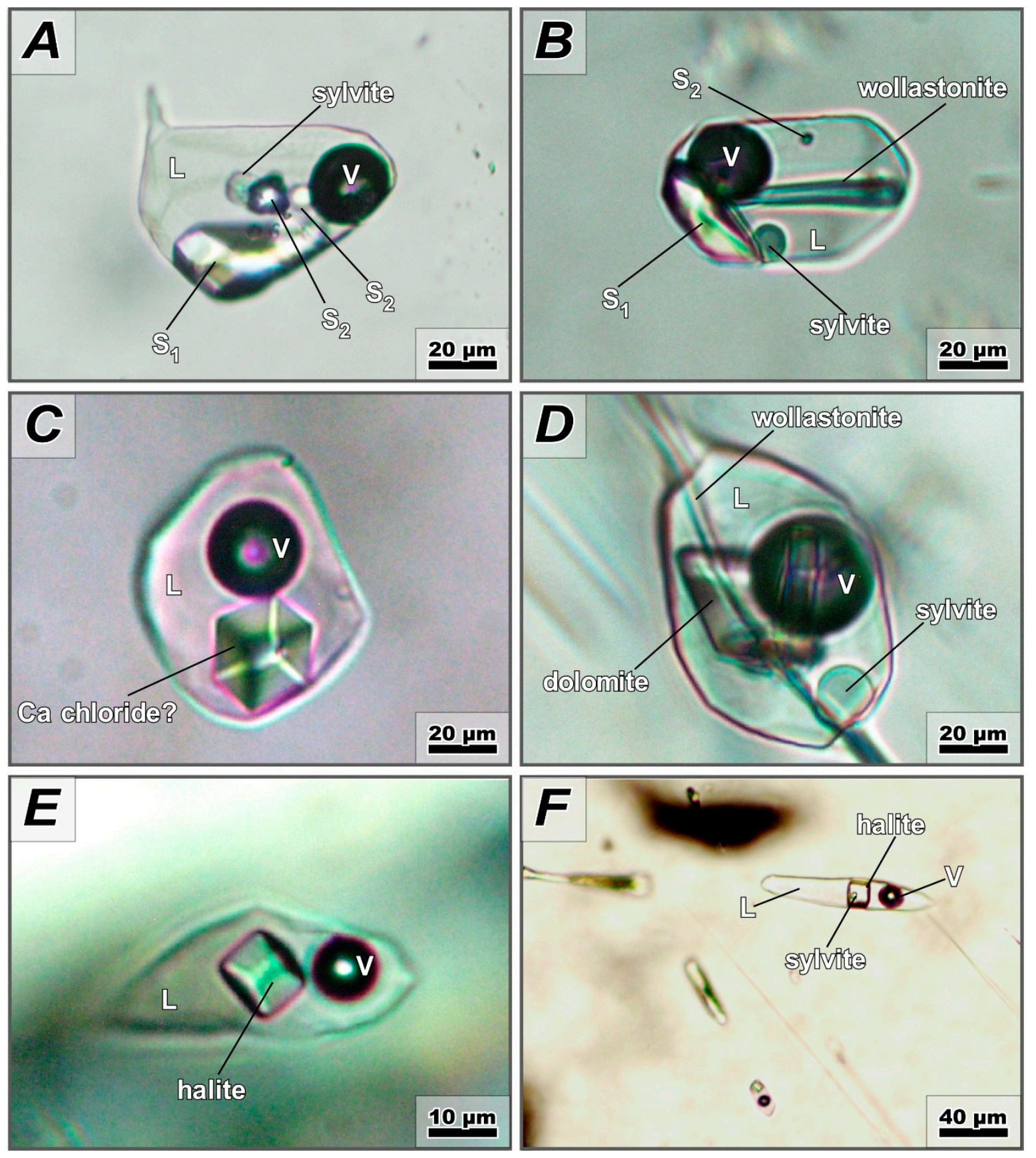

Figure 9. Photomicrographies of representative multiphase fluid inclusions from the El Pilote fluorite skarn, showing trapped solids (wollastonite, dolomite, and unknown phases $\mathrm{S}_{1}, \mathrm{~S}_{2}$ and $\mathrm{S}_{3} ; \mathbf{A}, \mathbf{B}, \mathbf{D}$ ) and daughter crystals (halite, sylvite and possible hydrophilite; $\mathbf{A}-\mathbf{F}$ ). 


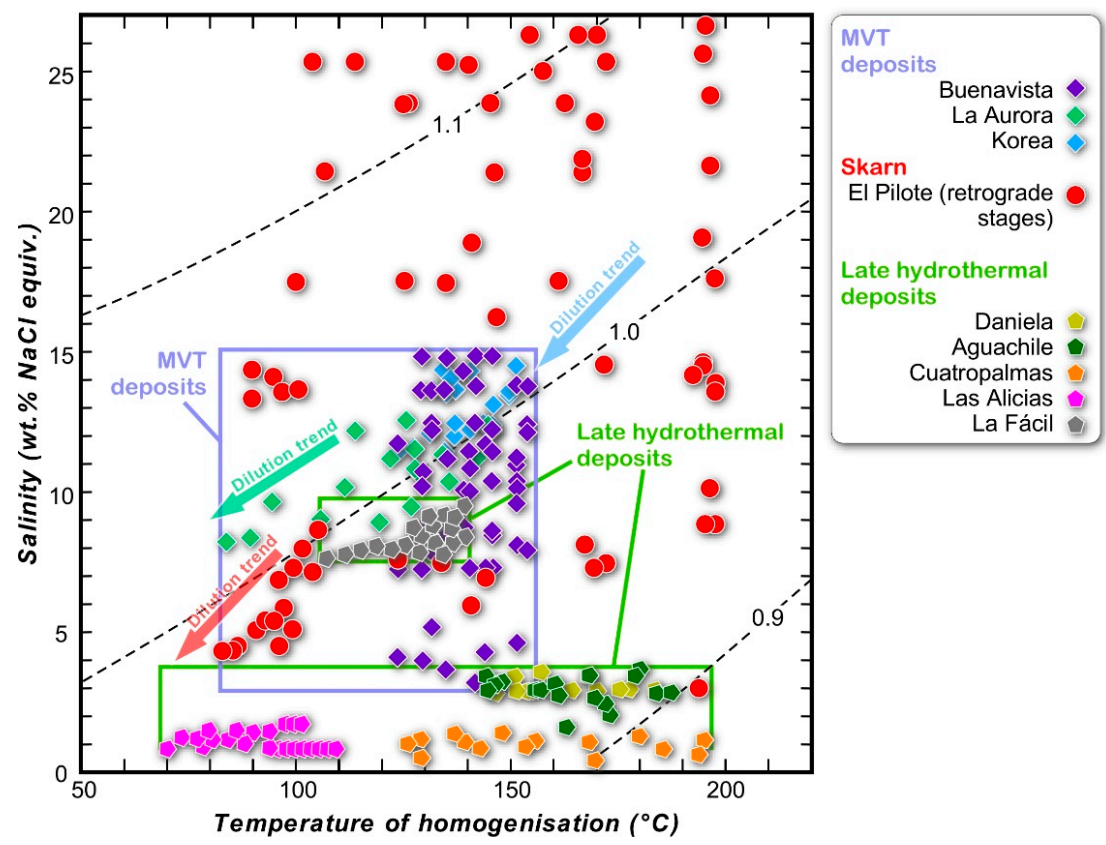

Figure 10. Correlation between temperature of homogenisation and calculated salinity of the fluorite deposits in the study area and other types of fluorite deposits in northern Coahuila state. The dilution trends marked in this figure correspond only to groups of fluid inclusion associations (FIA) that present such trends in a timeline in the same sample, as defined by the decrease of both temperatures of homogenisation and salinities with time, and the timeline was determined based on petrographic criteria (essentially, early to late growth zones within the same crystal).

\section{Discussion}

There are several types of deposits and depositional models that have been invoked for fluorite or fluorite-rich deposits in Mexico, which range from those associated with basinal brines to those associated with magmatic-hydrothermal phenomena and fluids (Table 2). The affinity with the MVT model of the fluorite deposits in the Buenavista area (with the exception of the El Pilote deposit) is not a matter for discussion in this paper, given that such a model is thoroughly documented already $[1-3,9,10,12,31]$. Also, the El Pilote deposit has been consistently described as an unusual example of fluorite skarns earlier [20,21], and its genesis will not be discussed any further. The soundly-established genetic affinities of both MVT-like and skarn fluorite deposits in the study areas allow for their inclusion in this paper to help with the identification of a formation model for the late hydrothermal fluorite-Be-U-Mo-P-V deposits in the Aguachile-Cuatro Palmas area. Other models, like those explored for exceptional deposits such as Las Cuevas, can be associated with an extended MVT "family" [37] across the rimming regions of the paleo-Gulf of Mexico. However, such a deposit cannot compare with any of the ranges of salinity for mineralising fluids, mineralogy or geological configuration of the three types of fluorite deposits in the study area (Table 2), and it is necessary to call for different processes for mineral formation. With regard to the origin of the small U-rich mineralisations in the study area, two alternative scenarios arise: (A) a close association between them and the same basinal brines that originated the MVT-like deposits that predate them, with possible linkages with $U$ red bed-hosted deposits, or (B) a strong association of these deposits with fluids that were exsolved from cooling hypabyssal rocks nearby or meteoric waters affected by the residual heat that remained after the emplacement of intrusive rocks. Similarly to El Pilote, the 33 Ma Be-rich fluorite Aguachile deposit has been traditionally described as part of the skarn "family" [3,6,18,28,34], in which it would correspond to the shallowest portions of retrograde associations (possibly epithermal). This hypothesis is favoured by the association of the Aguachile deposit with alkaline to calc-alkaline intrusive rocks that are ascribed to the Eastern Mexican Alkaline Province (EMAP) [3]. 
Table 2. Comparative existing models for the formation of fluorite or fluorite-rich hydrothermal deposits in Mexico.

\begin{tabular}{|c|c|c|c|c|c|c|c|}
\hline Case Example & Type of Deposit & Substances & Model of Formation & $\mathrm{T}\left({ }^{\circ} \mathrm{C}\right)$ & $\begin{array}{c}\text { Salinity (wt.\% } \\
\text { NaCl Equivalent) }\end{array}$ & Comments & References \\
\hline \multirow[t]{3}{*}{$\begin{array}{l}\text { Las Cuevas \& Río } \\
\text { Verde, San Luis Potosí }\end{array}$} & Skarn-related & Fluorite & $\begin{array}{l}\text { Contact metamorphism and } \\
\text { retrograde hydrothermal fluids } \\
\text { from F-rich volcanic rocks }\end{array}$ & 60 to 130 & $\sim 0$ & & [38] \\
\hline & MVT & & $\begin{array}{l}\text { Diluted basinal brines reacting } \\
\text { with host limestones }\end{array}$ & 60 to 110 & 0 to 0.2 & & [32] \\
\hline & MVT-like & & $\begin{array}{l}\text { Diluted basinal brines reacting } \\
\text { with F-rich modified meteoric } \\
\text { water and host limestones }\end{array}$ & 49 to 177 & 0 to 1.9 (mostly 0.2 ) & $\begin{array}{l}\text { In this paper, we } \\
\text { favour this model }\end{array}$ & [37] \\
\hline $\begin{array}{l}\text { Bolaños \& San Martín } \\
\text { de Bolaños, Jalisco }\end{array}$ & Epithermal & $\begin{array}{c}\text { Polymetallic, rich in } \\
\text { fluorite }\end{array}$ & $\begin{array}{l}\text { Essentially Ag-rich } \\
\text { intermediate sulphidation } \\
\text { deposits with stages of } \\
\text { mineralisation very rich in } \\
\text { fluorite, deposited through } \\
\text { boiling or conductive cooling }\end{array}$ & 150 to 340 & 0 to 16 & & [39-42] \\
\hline $\begin{array}{l}\text { Several small deposits } \\
\text { in Central Mexico }\end{array}$ & Tin rhyolites & Sn & $\begin{array}{l}\text { Fumarolic deposits associated } \\
\text { with extremely differentiated } \\
\text { F-rich rhyolites and rhyodacites }\end{array}$ & n.a. & n.a. & & {$[3,43]$} \\
\hline Buenavista, Coahuila & MVT & Fluorite & $\begin{array}{l}\text { Dense F-rich basinal brines that } \\
\text { reacted with platform and } \\
\text { reefal carbonates }\end{array}$ & 50 to 155 & 5.7 to 18.1 & & {$[1,2,9-12]$, this paper } \\
\hline El Pilote, Coahuila & Skarn & Fluorite & $\begin{array}{l}\text { Shallow hypabyssal rocks with } \\
\text { associated hydrothermal fluids } \\
\text { that dissolved pre-existing } \\
\text { MVT-like fluorite mantos, and } \\
\text { fluorite re-precipitated around } \\
\text { the skarn }\end{array}$ & 78 to 423 & 5 to 34 & $\begin{array}{l}\text { Also, } 24.5 \text { to } 29.1 \\
\text { wt. } \% \mathrm{CaCl}_{2} \text { fluids }\end{array}$ & {$[20,21]$, this paper } \\
\hline $\begin{array}{l}\text { Aguachile \& Cuatro } \\
\text { Palmas, Coahuila }\end{array}$ & $\begin{array}{l}\text { Shallow } \\
\text { hydro-thermal }\end{array}$ & $\begin{array}{l}\text { Fluorite, Be, } \mathrm{U}, \mathrm{Mo} \text {, } \\
\text { etc. }\end{array}$ & $\begin{array}{l}\text { Fluids largely exsolved from } \\
\text { cooling hypabyssal alkaline to } \\
\text { calc-alkaline rocks that reacted } \\
\text { with host carbonate rocks }\end{array}$ & 70 to 180 & 0.9 to 8.8 & $\begin{array}{l}\text { Fluids generally } \\
\text { below } 4 \text { wt. } \% \mathrm{NaCl} \\
\text { equivalent }\end{array}$ & {$[5,6]$, this paper } \\
\hline
\end{tabular}

Key: MVT = Mississippi Valley Type; $n$ a = not available; $\mathrm{T}$ = temperature. Notes: See ages for most of the deposits featured in this table in [3]. In the Las Cuevas case; we have consigned all the formation models available in the literature but are not discussed in this paper; see discussion in [37]. 


\subsection{Constraints from Fluid Inclusions}

The temperatures of homogenisation (Th) in MVT-like fluorite deposits studied in this paper range between $50{ }^{\circ} \mathrm{C}$ and $152{ }^{\circ} \mathrm{C}$, and salinities of inclusion fluids range between 5 and $15.5 \mathrm{wt} . \% \mathrm{NaCl}$ equivalent. Several MVT-like stratabound fluorite deposits in northeastern Mexico show ranges of Th and salinity $[1,2,9,10,12]$ that are similar to those determined in this study for the Buenavista, Korea and La Aurora deposits. In fluid inclusions from late fluorite-Be-U-Mo-P-V hydrothermal deposits, Th are higher and salinities lower than in MVT-like deposits (between $70{ }^{\circ} \mathrm{C}$ and $180{ }^{\circ} \mathrm{C}$, and between 0.4 and 8.8 wt.\% $\mathrm{NaCl}$ equivalent). With the sole exception of the Las Alicias deposit, all mineralising fluids in late hydrothermal deposits have salinities below $4 \mathrm{wt} . \% \mathrm{NaCl}$ equivalent and Th up to $200{ }^{\circ} \mathrm{C}$, whereas MVT-like deposits record salinities way above $4 \mathrm{wt} . \% \mathrm{NaCl}$ equivalent and Th below $160{ }^{\circ} \mathrm{C}$ (Figure 10). Fluid inclusion associations from retrograde stages of the El Pilote deposit display Th similar to those in late hydrothermal deposits, but their salinities are distinctively much higher (Figure 10) and include calcic brines (Table 1). Despite that their ranges of variation largely overlap those of MVT-like fluorite deposits, the ranges in Th and salinity of late hydrothermal fluids are similar to those in many types of shallow ore deposits, either retrograde stages in skarns or in epithermal deposits e.g., [44,45]. Another characteristic that the late hydrothermal deposits at La Fácil and Las Alicias share with MVT-like deposits in the region is the occurrence of hydrocarbon-rich inclusions (that indicate heterogeneous trapping with aqueous fluids in both types of deposits), which are absent at the El Pilote skarn. Therefore, it is likely that late shallow and low-temperature hydrothermal systems entrained basinal brines that were similar to those responsible for the formation of MVT-like fluorite deposits, and were still able to precipitate fluorite (Figure 11). Relatively low temperatures are required to avoid the cracking of hydrocarbons, which makes particulary relevant that late hydrothermal mineral associations with hydrocarbon-bearing fluid inclusions yielded temperatures of homogenisation up to $140{ }^{\circ} \mathrm{C}$ (Table 1, Figure 10). However, the solubility of fluorite increases with temperature and salinity in $\mathrm{Na}-\mathrm{K}-\mathrm{Cl}$ solutions at ranges of temperature that are compatible with shallow hydrotermal systems [46]. The precipitation of fluorite under low temperatures from low salinity fluids agrees with thermodynamic models in which the solubility of fluorite decreases steadily under $100{ }^{\circ} \mathrm{C}$ [46]. Higher temperatures, which favour the dissolution of fluorite can be expected for mineralising fluids at depth. Therefore, fluorite in late hydrothermal deposits is likely to have come from dissolved material from pre-existing MVT-like deposits, as documented for the fluorite deposits associated with the El Pilote skarn [20,21] (Figure 11).

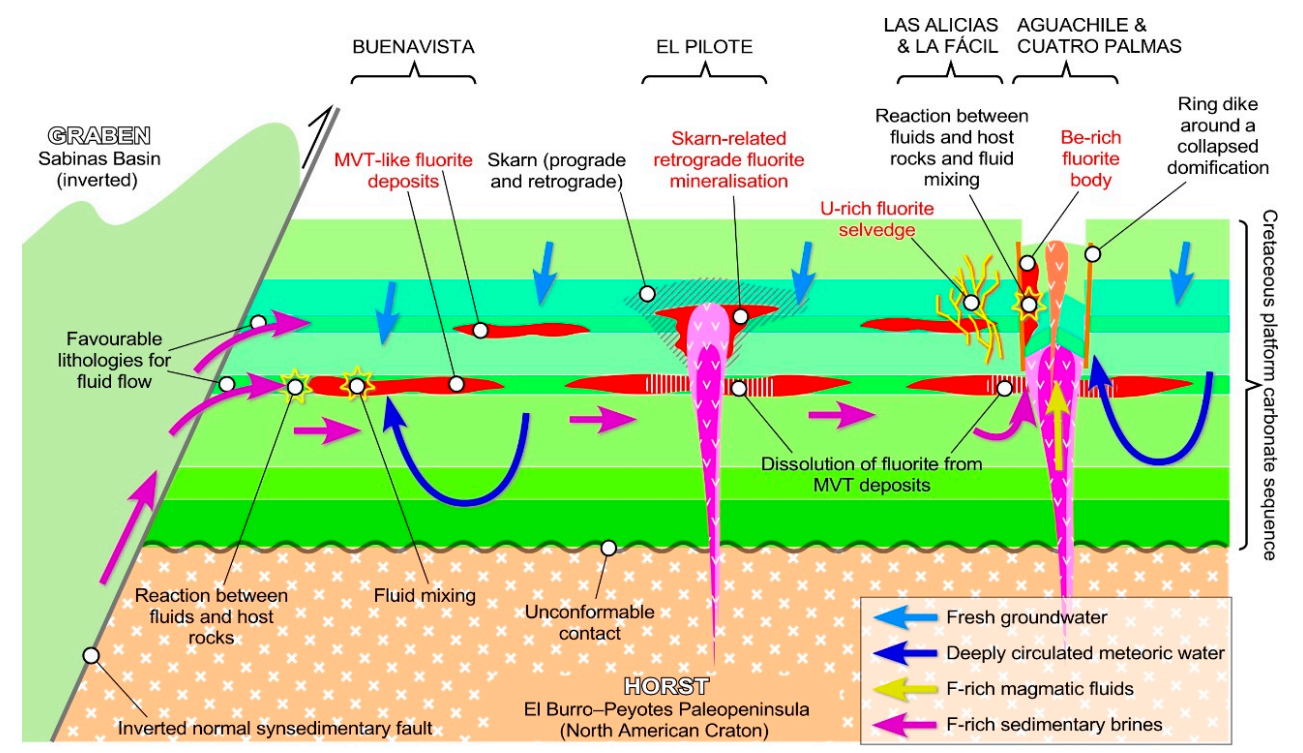

Figure 11. General genetic model for the formation of MVT-like, skarn, and shallow hydrothermal fluorite deposits in northern Coahuila (northeastern Mexico), and the related sources for fluids and elements that constitute the different deposits. See discussion for details. 


\subsection{Toward a Genetic Model for F-Be-U-Mo-P-V Deposits}

Uranium deposits in northern Mexico may be either associated with the magmatic-hydrothermal or sedimentary-diagenetic realms [3,31]. Thus, the occurrence of U-rich deposits may not stand for itself as helpful in discriminating between such realms, but Be-rich deposits may do so. The most significant beryllium ore deposits are granitic pegmatites and hydrothermal-metasomatic deposits [47]. Among the latter can be counted late hydrothermal fluorite-Be deposits associated with greisens or calc-alkaline skarns/porphyries [48-53] and alkaline granites [54-56], especially in volcanic and shallow-level intrusives for either case [57,58]. Important Be concentrations are also notorious in association with coal deposits by their interaction with hydrothermal fluids carrying Be mobilised from other rocks [58,59]. Be in epithermal deposits would have been "removed in the form of fluoride complexes by a hydrothermal fluid from a devitrifying topaz rhyolite at temperatures between $100^{\circ}$ and $200^{\circ} \mathrm{C}$ and at a near neutral $p H^{\prime \prime}$ (sic), [60] or from granitic rocks in general by dilute low-temperature hydrothermal fluids [59]. Be minerals would precipitate as the formation of fluorite due to scavenging of Ca from host limestones removed fluorine from solution, thus destabilising beryllium fluorides in solution [60], which is a likely mechanism for mineral precipitation of Be-rich hydrothermal associations in the study area. The formation of the fluorite-bearing Baiyanghe Be-U-Mo deposit in China is associated with leaching of these metals from granite porphyries [53]. Needless to say, the fluorite-Be-U-Mo association in that deposit is very similar to the ones described in this paper. Be- and U-Mo-rich mineral associations with fluorite in the Aguachile-Cuatro Palmas area are restricted to late hydrothermal deposits, and do not occur in the MVT-like deposits that predated them. In addition, no U-rich fluorite has been found in MVT-like deposits in the study area; it occurs only in late hydrothermal veins (Figure 5F). This makes a difficult case for a substratum, earlier than MVT-like deposits, that might provide Be, $\mathrm{U}$ and Mo by means of its leaching by basinal brines. Instead, the most likely (and simple) explanation would be that such elements were provided by hydrothermal fluids that had been exsolved from shallow alkaline to calc-alkaline hypabyssal rocks. The incorporation of $\mathrm{F}^{-}$, an efficient complexating ion for Be at low temperatures (see above), by hydrothermal fluids could occur at a broad range of temperatures due to fluorite breakdown in pre-existing MVT-like deposits, and the temperatures obtained in this study for late hydrothermal fluids are compatible with these. However, the occurrence of hydrocarbons in fluid inclusions of late hydrothermal minerals indicates that basinal brines would have been entrained by fluids exsolved from or mobilised by hypabyssal intrusions (Figure 11). Therefore, $\mathrm{F}^{-}$in late hydothermal stages would not necessarily come from the dissolution of fluorite from MVT-like deposits but could be provided by basinal brines instead. Such an explanation also accounts for the differences in salinity of mineralising fluids between MVT-like fluorite and late hydrothermal deposits ( 5 to 15.5 and 0.4 to $8.8 \mathrm{wt} . \% \mathrm{NaCl}$ equivalent, respectively). In such a scenario, the salinity of the fluids that were directly associated with hypabyssal intrusives, whether they were magmatic or magmatically driven, was necessarily much lower than the salinity of basinal brines, and even meteoric fluids could have been entrained by the late hydrothermal episode. However, the occurrence of alkaline to calc-alkaline felsic rocks in the area attests to the possibility that the source of $\mathrm{F}^{-}$were magmatic and that beryllium fluoride complexes were exsolved from crystallising hypabyssal rocks that were cooling down. In any case, hydrothermal mineral precipitation occurred as described by [60] for fluorite and bertrandite after beryllium fluoride complexes.

\subsection{Regional Implications}

Hydrothermal U-Mo associations linked to shallow magmatism are not unheard of in northern Mexico, as they are conspicuous in the Sierra de Peña Blanca area, in association with alkaline magmatism [61-66], as part of the Eocene cluster of volcanic related uranium deposits of central-east Chihuahua $[3,64]$. Also, Be and $U$ have a tight geochemical affinity in highly differentiated volcanic rocks $[33,57,64,67-70]$, which would imply that the hydrothermal products from such rocks may contain similar associations in incompatible elements. Such metal associations are indicative of shallow low-temperature magmatic-hydrothermal in origin. Therefore, the late hydrothermal deposits in the 
Aguachile-Cuatro Palmas area and skarns in the La Encantada-Buenavista area can be associated with an Oligocene event (partly Eocene) in the evolution of such magmatism. The F-Be-U association in these deposits, including other lithophile elements, has been reported as part of an ideal vertical zonation with, in a deepening sequence, (A) "fumarolic" Sn in topaz-rich rhyolites, (B) F-Be-U in shallow rocks associated with such rhyolites, (C) U-F-Be-Sn-W-Mo in sub-volcanic breccias, veins and replacements, (D) Mo-W-Sn( $\pm \mathrm{Nb}-\mathrm{Ta}-\mathrm{Be}-\mathrm{U}-\mathrm{Th})$ in porphyries, including Climax-type Mo porphyries, and (E) $\mathrm{Li}-\mathrm{Nb}-\mathrm{Ta}-\mathrm{Be}-\mathrm{Sn}-\mathrm{U}$ in pegmatites [57,68-70], or even REE deposits [33]. Therefore, the occurrence of $\mathrm{F}-\mathrm{Be}-\mathrm{U}-\mathrm{Mo}-\mathrm{P}-\mathrm{V}$ deposits in the Aguachile-Cuatro Palmas area makes a plausible case for a shallow set of deposits associated with such a tract of ore deposits. The feasibility of this model would, in turn, support future exploration endeavours that aim at several strategic substances in this region and other areas along the Eastern Mexico Alkaline Province (EMAP).

Central-east Chihuahua and Coahuila contain part of the intraplate peralkaline and calc-alkaline magmatism that extends northwards into Texas as the Trans-Pecos belt $[8,67]$ and southwards into the EMAP [3]. The ill-defined metallogeny of the late hydrothermal fluorite deposits in Coahuila needs further studies to comprehensively place these deposits in the evolution of the EMAP and Trans-Pecos ensemble. However, their formation can be ascribed to the soutward-younging [3] evolution of the Cenozoic intraplate magmatic-hydrothermal activity of eastern Mexico.

\subsection{Sources of Fluids and Mechanisms of Mineralisation for $\mathrm{F}-\mathrm{Be}-U-\mathrm{Mo}-\mathrm{P}-\mathrm{V}$ Deposits}

According to the previous discussion, upwelling mineralising fluids for late fluorite-Be-U-Mo-P-V hydrothermal deposits were likely to be magmatic-derived in order to account for the elemental associations. However, in the La Fácil deposit, the occurrence of heterogeneous trapping with inmiscible hydrocarbons and aqueous fluids with relatively high salinities (between 7.9 and $8.8 \mathrm{wt} . \% \mathrm{NaCl}$ equivalent) suggests that basinal brines were entrained by mineralising fluids.

In summary, the possible sources for mineralising fluids and late hydrothermal minerals can be categorised as follows (see Figure 11):

1. $\mathrm{F}^{-}$was carried by hydrocarbon-rich saline basinal brines that were diluted by upwelling low-salinity magmatic fluids that carried Be (plus U and Mo) and the beryllium fluoride complexes thus formed were transported to shallow depths, with some participation of meteoric fluids heated by alkaline to calc-alkaline intrusives.

2. Fluorite was dissolved from pre-existing MVT-like deposits by upwelling moderatery saline magmatic fluids that carried Be (plus U and Mo), such process released hydrocarbons contained in fluid inclusions, and the beryllium fluoride complexes thus formed were transported to shallow depths.

3. Beryllium fluoride complexes (plus U, Mo, etc.) were exsolved from highly evolved alkaline to calc-alkaline intrusives along with moderately saline aqueous fluids, and some hydrocarbon-rich saline basinal brines were entrained by such fluids, with or without the entrainment of heated meteoric water.

The dilution trends that characterise most of the fluid inclusion associations of late hydrothermal deposits suggest that, regardless of the ultimate origin of upwelling mineralising fluids (magmatic fluids or sedimentary brines), they interacted with low temperature and low salinity fluids. Such fluids are likely to be meteoric in origin, whether shallow or deeply circulated. The most likely possibility is that these fluids were shallow and the consubstantial decrease in temperature of upwelling fluids constituted an effective mechanism for fluorite precipitation. Most fluorite-Be-U-Mo-P-V hydrothermal deposits are veinlets and stringers, but the mineralised bodies in the Aguachile deposit are irregularly shaped and were developed into host carbonate rocks (Figure 2). Such a feature is suggestive of hydrothermal karstification, similar to the Las Cuevas MVT-like deposits [32]. Also, acidic mineralising fluids would have been neutralised by their reaction with host rocks, thus favouring 
the precipitation of fluorite and other Ca-bearing minerals in the associated minerals (crandallite, powellite, gypsum, calcite, aragonite).

\section{Conclusions}

Three types of fluorite deposits occur in the Aguachile-Cuatro Palmas and the Buenavista areas in Northern Coahuila (northeastern Mexico): MVT-like, skarns and shallow fluorite-Be-U-Mo-V-P hydrothermal deposits. MVT-like fluorite deposits that were overprinted by skarns and shallow hydrothermal deposits. Only the ascription of the latter to a certain genetic model was not hitherto addressed.

The highest temperatures of homogenisation and salinities, $\mathrm{CaCl}_{2}$-rich brines, and the broadest ranges of salinity occur in inclusion fluids of skarns (prograde and retrograde associations). The lowest salinities and "intermediate" temperatures of homogenisation occur in shallow fluorite-Be-U-Mo-V-P hydrothermal deposits. The lowest temperatures of homogenisation and "intermediate" salinities occur in MVT-like deposits. Only MVT-like deposits show systematic evidence for their formation after the heterogeneous trapping of aqueous fluids and hydrocarbons in fluid inclusion associations (FIAs), and late hydrothermal deposits may eventually record such FIAs. These characteristics suggest distinct sources and evolution for mineralising fluids attributed to each type of deposits.

The occurrence of magmatic fluids in late hydrothermal deposits concurs with the F-Be-U-Mo highly lithophile elemental association, most likely linked to a retrograde skarn or epithermal model. The occurrence of basinal brines in these deposits agrees with hydrocarbons accompanying aqueous fluids with salinities similar to those in MVT-like deposits (F-rich). However, fluorite might equally have come from the dissolution and reprecipitation of earlier MVT-like fluorite deposits, similarly to the case of the El Pilote skarn deposit.

Low salinities in inclusion fluids associated with late F-Be-U-Mo-V-P hydrothermal deposits and the dilution trends shown by the behaviour of microthermometric data suggest that the interaction between upwelling fluids and fresh meteoric water had a key role in mineral precipitation. Also, irregularly-shaped fluorite bodies on carbonate rocks in the Aguachile deposit suggest that their formation was produced through hydrothermal karstification and mineral precipitation by means of the reaction of mineralising fluids and host rocks. Be minerals would have precipitated as beryllium fluorides in solution were destabilised by the scavenging of $\mathrm{F}^{-}$by $\mathrm{Ca}$ (that came abundantly from host limestones) to precipitate fluorite.

The elemental association in the late fluorite-Be-U-Mo-V-P hydrothermal deposits in the Aguachile-Cuatro Palmas area suggests that these deposits represent the upper part of a possible tract of deeper deposits of highly lithophile elements that may increase the potential metallogenic interest of the study area and the rest of the Eastern Mexico Alkaline Province.

Author Contributions: A.C., conceptualisation, writing, graphic design, proof editing, funding acquisition; E.G.-P., funding, sampling, analyses, funding acquisition; A.R., M.-C.B., C.L., analyses, data processing; L.E.G.-R., D.G.-R., data processing, graphic design; C.F.A.-R., E.F.-G., graphic design.

Funding: The research in this paper was financed by means of 155662 and IN101113-3 research projects granted by CONACyT and the PAPIIT program of the Universidad Nacional Autónoma de México (UNAM), respectively. Additional funding was provided through personal budgets to AC and EGP by the Instituto de Geología and the Centro de Geociencias of the UNAM.

Acknowledgments: This paper is partly based in the master thesis of Claire Legouix at the École Nationale Supérieure de Géologie at Nancy, France. The SEM studies benefitted from the assitance and expertise of Alain Kohler at the Universite de Lorraine. This manuscript has benefitted from the comments of a handling editor and three anonymous reviewers that are wholeheartedly thanked for their constructive efforts.

Conflicts of Interest: The authors declare no conflict of interest. 


\section{References}

1. González-Sánchez, F.; Camprubí, A.; González-Partida, E.; Puente-Solís, R.; Canet, C.; Centeno-García, E.; Atudorei, V. Regional stratigraphy and distribution of epigenetic stratabound clestine, fluorine, barite and $\mathrm{Pb}-\mathrm{Zn}$ deposits in the MVT province of northeastern Mexico. Mineral. Deposita 2009, 44, 343-361. [CrossRef]

2. González-Sánchez, F.; Puente-Solís, R.; González-Partida, E.; Camprubí, A. Estratigrafía del Noreste de México y su relación con los yacimientos estratoligados de fluorita, barita, celestina y Zn-Pb. Bol. Soc. Geol. Mex. 2007, 59, 32-45.

3. Camprubí, A. Tectonic and metallogenic history of Mexico. In Tectonics, Metallogeny, and Discovery: The North American Cordillera and Similar Accretionary Settings; Colpron, M., Bissig, T., Rusk, B.G., Thompson, J.F.H., Eds.; Society of Economic Geologists: Littleton, CO, USA, 2013; Volume 17, pp. 201-243.

4. González-Partida, E.; Camprubí, A.; Pironon, J.; Alfonso, P.; Cienfuegos-Alvarado, E.; Morales-Puente, P.A.; Canet, C.; González-Ruiz, L.E.; Díaz-Carreño, E.H. Modelo de formación de los yacimientos estratoligados de $\mathrm{Cu}$ en lechos rojos de Las Vigas (Chihuahua, México). Bol. Soc. Geol. Mex. 2017, 69, 611-635. [CrossRef]

5. McAnulty, W.N.; Sewell, C.R.; Rasberry, J.M. Geology and Fluorspar ore Deposits in Cerro Aguachile, Pico Etereo District, Coahuila, Mexico; The Dow Chemical Company: Midland, MI, USA, 1960; unpublished report.

6. McAnulty, W.N.; Sewell, C.R.; Atkinson, D.R.; Rasberry, J.M. Aguachile Beryllium-Bearing Fluorspar District, Coahuila, Mexico. Geol. Soc. Am. Bull. 1963, 74, 735-744. [CrossRef]

7. Barker, D.S. Cenozoic magmatism in the Trans-Pecos province: Relation to the Rio Grande Rift. In Rio Grande Rift: Tectonics and Magmatism; Riecker, R.E., Ed.; American Geophysical Union: Washington, DC, USA, 1979; pp. 382-392.

8. Griffin, W.R.; Foland, K.A.; Stern, R.J.; Leybourne, M.I. Geochronology of bimodal alkaline volcanism in the Balcones igneous province, Texas: Implications for Cretaceous intraplate magmatism in the northern Gulf of Mexico magmatic zone. J. Geol. 2010, 118, 1-21. [CrossRef]

9. González-Partida, E.; Carrillo-Chávez, A.; Grimmer, J.O.W.; Pironon, J.; Mutterer, J.; Levresse, G. Fluorite deposits at Encantada-Buenavista, Mexico: Products of Mississippi Valley type processes. Ore Geol. Rev. 2003, 23, 107-124. [CrossRef]

10. González-Partida, E.; Carrillo-Chávez, A.; Grimmer, J.O.W.; Pironon, J. Petroleum-rich fluid inclusions in fluorite, Purisima Mine, Coahuila, Mexico. Int. Geol. Rev. 2002, 44, 755-764. [CrossRef]

11. González-Partida, E.; Camprubí, A.; Canet, C.; González-Sánchez, F. Fisicoquímica de salmueras e hidrocarburos en cuencas petroleras y en depósitos minerales tipo Mississippi Valley y asociados. Parte I: Temperatura, presión y composición de inclusiones fluidas. Bol. Soc. Geol. Mex. 2008, 60, 11-22.

12. González-Partida, E.; Camprubí, A.; Canet, C.; González-Sánchez, F. Fisicoquímica de salmueras e hidrocarburos en cuencas petroleras y en depósitos minerales tipo Mississippi Valley y asociados. Parte II: Ejemplos de la Cuenca de Sabinas y la Cuenca del Sureste, México. Bol. Soc. Geol. Mex. 2008, 60, $23-42$.

13. Duex, T.W.; Henry, C.D. Uranium mobility in late magmatic and hydrothermal processes: Evidence from fluorite deposits, Texas and Mexico. In Uranium Deposits in Volcanic Rocks. Proceedings of a Technical Committee Meeting, El Paso, 1984; STI/PUB/690; International Agency of Atomic Energy (IAEA): Vienna, Austria, 1985; pp. 365-377.

14. Smith, C.I. (Ed.) Review of the geologic setting, stratigraphy, and facies distribution of the Lower Cretaceous in Northern Mexico. In Lower Cretaceous Stratigraphy and Structure, Northern Mexico; West Texas Geological Society Publications: Midland, TX, USA, 1981; pp. 74-81.

15. Eguiluz de Antuñano, S. Geologic Evolution and Gas Resources of the Sabinas Basin in Northeastern Mexico. In The Western Gulf of Mexico Basin; Bartolini, C., Buffler, R.T., Cantú-Chapa, A., Eds.; AAPG Memoir: Tulsa, OK, USA, 2001; Volume 75, pp. 241-270.

16. Rivera-Martínez, C.; Santiago-Carrasco, B.; Barbosa-Luna, D. Informe Geológico-Minero de la Carta Cuatro Palmas h13-d38, Escala 1:50,000; Servicio Geológico Mexicano: Pachuca, Hidalgo, Mexico, 2005.

17. Daugherty, F.W. Geology of the Pico Etéreo Area, Acuña Municipality, Coahuila. Ph.D. Dissertation, University of Texas at Austin, Austin, TX, USA, 1962.

18. Sánchez-Bermeo, G.; Jiménez-Hernández, A.; Caballero-Martínez, J.A. Informe de la Carta Geológico-Minera Manuel Benavides Clave H13-9, Escala 1,250,000, Estados de Coahuila y Chihuahua; Consejo de Recursos Minerales, Gerencia de Geología y Geoquímica, Oficina Regional Coahuila: Saltillo, Coahuila, Mexico, 2002; 100p. 
19. Price, J.G.; Henry, C.D. Stress orientations during Oligocene volcanism in the Trans-Pecos Texas: Timing the transition from Laramide Compression to Basin and Range tension. Geology 1984, 12, 238-241. [CrossRef]

20. Levresse, G.; Tritlla, J.; Villareal, J.; González-Partida, E. The “El Pilote” fluorite skarn: A crucial deposit in the understanding and interpretation of the origin and mobilization of F from northern Mexico deposits. J. Geochem. Explor. 2006, 89, 205-209. [CrossRef]

21. Levresse, G.; Tritlla, J.; Solorio-Munguía, J.G.; Valencia, V.; Pinto-Linares, P.J. Fluid inclusions and U/Pb dating of the El Pilote Fluorite skarn occurrence: Metallogenic implications. Compt. Rendus Geosci. 2011, 343, 342-350. [CrossRef]

22. Kesler, S.E. Informe Final Sobre el Proyecto de Fluorita en Yacimientos de Fluorita y de Plomo-Zinc-Plata; Consejo de Recursos Minerales: Pachuca, Mexico, 1974; 114p, Unpublished report.

23. Chairez-Blanco, J.; Flores, T. Informe de la Visita de Reconocimiento de la Parte Central de la Sierra La Vasca, Localizada en el Municipio de Ocampo, Coahuila; Consejo de Recursos Minerales: Pachuca, Hidalgo, Mexico, 1983; 12p, Unpublished report.

24. Orozco-Jiménez, R. Reconocimiento Geológico-Minero de la Sierra de la Vasca, Municipio de Ocampo, Coahuila; Consejo de Recursos Minerales: Pachuca, Hidalgo, Mexico, 1985; 14p, Unpublished report.

25. Sánchez-Alvarado, P.; Pérez-Martínez, H.; González-Faustino, G.; Olvera-Cano, M.A. Estudio Geológico del Área de La Morena, Municipio de Ocampo, Coahuila; Consejo de Recursos Minerales: Pachuca, Hidalgo, Mexico, 1985; 111p, Unpublished report.

26. Iriondo, A.; Kunk, M.J.; Winick, J.A.; CRM. 40Ar/39Ar Dating Studies of Minerals and Rocks in Various Areas in Mexico: USGS/CRM Scientific Collaboration (Part I); USGS Open-File Report 03-020; United States Geological Survey: Denver, CO, USA, 2003.

27. Iriondo, A.; Kunk, M.J.; Winick, J.A.; CRM. 40Ar/39Ar Dating Studies of Minerals and Rocks in Various Areas in Mexico: USGS/CRM Scientific Collaboration (Part II); USGS Open-File Report 04-1444; United States Geological Survey: Denver, CO, USA, 2003.

28. Takeda, H. Las Características de la Mineralización de los Depósitos de Plomo-Zinc-Plata en las Calizas de la Parte Norte de la Sierra Madre Oriental, México; Consejo de Recursos Minerales, VI Seminario Interno Sobre Exploración Geológico-Minera: Pachuca, Hidalgo, Mexico, 1977; pp. 239-277.

29. Chairez-Blanco, J. El Yacimiento de Au, Ag y Cu de Mina Fronteriza, Mpio. de Ocampo, Coah; Consejo de Recursos Minerales: Pachuca, Hidalgo, Mexico, 1993; 11p, Unpublished report.

30. Ostendorf, J.; Henjes-Kunst, F.; Schneider, J.; Melcher, F.; Gutzmer, J. Genesis of the carbonate-hosted tres marias $\mathrm{Zn}-\mathrm{Pb}-(\mathrm{Ge})$ deposit, Mexico: Constraints from $\mathrm{Rb}-\mathrm{Sr}$ sphalerite geochronology and $\mathrm{Pb}$ isotopes. Econ. Geol. 2017, 112, 1075-1087. [CrossRef]

31. Camprubí, A. The metallogenic evolution in Mexico during the Mesozoic, and its bearing in the Cordillera of Western North America. Ore Geol. Rev. 2017, 81, 1193-1214. [CrossRef]

32. Levresse, G.; González-Partida, E.; Tritlla, J.; Camprubí, A.; Cienfuegos-Alvarado, E.; Morales-Puente, P. Fluid origin of the world-class, carbonate-hosted Las Cuevas fluorite deposit (San Luis Potosí, Mexico). J. Geochem. Explor. 2003, 78-79, 537-543. [CrossRef]

33. McLemore, V.T. Rare Earth Elements (REE) Deposits Associated with Great Plain Margin Deposits (Alkaline-Related), Southwestern United States and Eastern Mexico. Resources 2018, 7, 8. [CrossRef]

34. Levinson, A.A. Beryllium-fluorine mineralization at Aguachile Mountains, Coahuila, Mexico. Am. Mineral. $1962,47,67-74$.

35. Bodnar, R.J. Revised equation and table for determining the freezing point depression of $\mathrm{H}_{2} \mathrm{O}-\mathrm{NaCl}$ solutions. Geochim. Cosmochim. Acta 1993, 57, 683-684. [CrossRef]

36. Bodnar, R.J.; Sterner, S.M.; Hall, D.L. SALTY: A FORTRAN program to calculate compositions of fluid inclusions in the system NaCl-KCl-H${ }_{2} \mathrm{O}$. Comput. Geosci. 1989, 15, 19-41. [CrossRef]

37. González-Partida, E.; Camprubí, A.; Carrillo-Chávez, A.; Díaz-Carreño, E.H.; González-Ruiz, L.E.; Farfán-Panamá, J.L.; Cienfuegos-Alvarado, E.; Morales-Puente, P.; Vázquez-Ramírez, J.T. Giant fluorite mineralization in Central Mexico by means of exceptionally low salinity fluids: An unusual style among MVT deposits. Minerals 2019, in press.

38. González-Partida, E.; Camprubí, A. Evolution of mineralizing fluids in the $\mathrm{Zn}-\mathrm{Pb}-\mathrm{Cu}(-\mathrm{Ag} \pm \mathrm{Au})$ skarn and epithermal deposits of the world-class San Martín district, Zacatecas, Mexico. J. Geochem. Explor. 2006, 89, 138-142. [CrossRef] 
39. Ruiz, J.; Kesler, S.E.; Jones, L.M.; Sutter, J.F. Geology and geochemistry of the Las Cuevas fluorite deposit, San Luis Potosí, México. Econ. Geol. 1980, 75, 1200-1209. [CrossRef]

40. Lyons, J.I. Geology and ore deposits of the Bolaños silver district, Jalisco, Mexico. Econ. Geol. 1988, 83, 1560-1582. [CrossRef]

41. Scheubel, F.R.; Clark, K.F.; Porter, E.W. Geology, tectonic environment, and structural controls in the San Martín de Bolaños district, Jalisco, Mexico. Econ. Geol. 1988, 83, 1703-1720. [CrossRef]

42. Albinson, T.; Norman, D.I.; Cole, D.; Chomiak, B. Controls on the formation of low-sulfidation epithermal deposits in Mexico: Constraints from fluid inclusions and stable isotope data. Soc. Econ. Geol. Spec. Publ. 2001, 8, 1-32.

43. Albinson, T.; Rubio, M.A. Mineralogic and thermal structure of the Zuloaga vein, San Martín de Bolaños District, Jalisco, Mexico. Soc. Econ. Geol. Spec. Publ. 2001, 8, 115-132.

44. Huspeni, J.R.; Kesler, S.E.; Ruiz, J.; Tuta, Z.; Sutter, J.F.; Jones, L.M. Petrology and geochemistry of rhyolites associated with tin mineralization in northern Mexico. Econ. Geol. 1984, 79, 87-105. [CrossRef]

45. Camprubí, A.; Albinson, T. Epithermal deposits in México-An update of current knowledge, and an empirical reclassification. In Geology of México: Celebrating the Centenary of the Geological Society of México; Alaniz-Álvarez, S.A., Nieto-Samaniego, A.F., Eds.; Geological Society of America Special Paper; Geological Society of America: Boulder, CO, USA, 2007; Volume 422, pp. 377-415.

46. Zhang, W.; Zhou, L.; Tang, H.; Li, H.; Song, W.; Xie, G. The solubility of fluorite in Na-K-Cl solutions at temperatures up to $260{ }^{\circ} \mathrm{C}$ and ionic strengths up to $4 \mathrm{~mol} / \mathrm{kg} \mathrm{H}_{2} \mathrm{O}$. Appl. Geochem. 2017, 82, 79-88. [CrossRef]

47. Trueman, D.L.; Sabey, P. Beryllium. In Critical Metals Handbook; Gunn, G., Ed.; John Wiley \& Sons: New York, NY, USA, 2013; pp. 99-121.

48. Bulnaev, K.B. Origin of the fluorite-bertrandite-phenakite deposits. Geol. Ore Dep. 1996, 38, 128-136.

49. Bulnaev, K.B. Fluorine-beryllium deposits of the Vitim Highland, western Transbaikal region: Mineral types, localization conditions, magmatism, and age. Geol. Ore Dep. 2006, 48, 277-289. [CrossRef]

50. Kupriyanova, I.I.; Kukushkina, O.A.; Shpanov, E.P.; Kuvshinova, K.A. Fluorite Properties and Formation Conditions at the Beryllium-Fluorite Deposits in the Voznesensk Ore District (Far East Region). Geol. Ore Dep. 2001, 43, 481-493.

51. Stel'machonok, K.Z.; Ishkov, Y.M. Metal content of ore-forming solutions of the Ermakovka beryllium deposit (Western Transbaikalia). Geol. Geofiz. 2001, 42, 802-814.

52. Aleksandrov, S.M. Skarn-greisen deposits of the Lost River and Mount Ear ore field, Seward Peninsula, Alaska, United States. Geochem. Int. 2010, 48, 1220-1236. [CrossRef]

53. Li, X.; Wang, G.; Mao, W.; Wang, C.; Xiao, R.; Wang, M. Fluid inclusions, muscovite Ar-Ar age, and fluorite trace elements at the Baiyanghe volcanic Be-U-Mo deposit, Xinjiang, northwest China: Implication for its genesis. Ore Geol. Rev. 2015, 64, 387-399. [CrossRef]

54. Reyf, F.G.; Karmanov, N.S.; Ishkov, Y.M. Acid Be solutions at the Orot deposit and their relation to the intrusion of alkaline granites. Dokl. Earth Sci. 2005, 405, 1257-1260.

55. Grew, E.S.; Hazen, R.M. Beryllium mineral evolution. Am. Mineral. 2010, 99, 999-1021. [CrossRef]

56. Steenfelt, A.; Kolb, J.; Thrane, K. Metallogeny of South Greenland: A review of geological evolution, mineral occurrences and geochemical exploration data. Ore Geol. Rev. 2016, 77, 194-245. [CrossRef]

57. Burt, D.M.; Sheridan, M.F. Model for the formation of uranium/lithophile element deposits in fluorine-rich volcanic rocks. In Uranium in Volcanic and Volcaniclastic Rocks; Goodell, P.C., Waters, A.C., Eds.; AAPG Studies in Geology; American Association of Petroleum Geologists: Tulsa, OK, USA, 1980; Volume 13, pp. 99-110.

58. Dai, S.; Wang, X.; Seredin, V.V.; Hower, J.C.; Ward, C.R.; O’Keefe, J.M.K.; Huang, W.; Li, T.; Li, X.; Liu, H.; et al. Petrology, mineralogy, and geochemistry of the Ge-rich coal from the Wulantuga Ge ore deposit, Inner Mongolia, China: New data and genetic implications. Int. J. Coal Geol. 2012, 90-91, 72-99. [CrossRef]

59. Etschmann, B.; Liu, W.; Li, K.; Dai, S.; Reith, F.; Falconer, D.; Kerr, G.; Paterson, D.; Howard, D.; Kappen, P.; et al. Enrichment of germanium and associated arsenic and tungsten in coal and roll-front uranium deposits. Chem. Geol. 2017, 463, 29-49. [CrossRef]

60. Wood, S.A. Theoretical prediction of speciation and solubility of beryllium in hydrothermal solution to $30{ }^{\circ} \mathrm{C}$ at saturated vapor pressure: Application to bertrandite/phenakite deposits. Ore Geol. Rev. 1992, 7, 249-278. [CrossRef] 
61. Cárdenas-Flores, D. Volcanic stratigraphy and U-Mo mineralisation of the Sierra de Peña Blanca district, Chihuahua, México. In Uranium Deposits in Volcanic Rocks. Proceedings of a Technical Committee Meeting, El Paso, 1984; STI/PUB/690; International Agency of Atomic Energy (IAEA): Vienna, Austria, 1985; pp. 125-136.

62. George-Aniel, B.; Leroy, J.; Poty, B. Uranium deposits of the Sierra Peña Blanca: Three examples of mechanisms of ore deposit formation in a volcanic environment. In Uranium Deposits in Volcanic Rocks. Proceedings of a Technical Committee Meeting, El Paso, 1984; STI/PUB/690; International Agency of Atomic Energy (IAEA): Vienna, Austria, 1985; pp. 175-186.

63. George-Aniel, B.; Leroy, J.; Poty, B. Volcanogenic uranium mineralisations in the Sierra Pena Blanca District, Chihuahua, Mexico: Three genetic models. Econ. Geol. 1991, 86, 233-248. [CrossRef]

64. Goodell, P.C. Chihuahua City uranium province, Chihuahua, Mexico. In Uranium Deposits in Volcanic Rocks. Proceedings of a Technical Committee Meeting, El Paso, 1984; STI/PUB/690; International Agency of Atomic Energy (IAEA): Vienna, Austria, 1985; pp. 97-124.

65. Locardi, E. Uranium in acidic volcanic environments. In Uranium Deposits in Volcanic Rocks. Proceedings of a Technical Committee Meeting, El Paso, 1984; STI/PUB/690; International Agency of Atomic Energy (IAEA): Vienna, Austria, 1985; pp. 17-28.

66. Reyes-Cortés, M. Depósito de molibdeno asociado con uranio en Peña Blanca, México. In Uranium Deposits in Volcanic Rocks. Proceedings of a Technical Committee Meeting, El Paso, 1984; STI/PUB/690; International Agency of Atomic Energy (IAEA): Vienna, Austria, 1985; pp. 161-174.

67. Wenrich, K.J. Geochemical characteristics of uranium-enrichedvolcanic rocks. In Uranium Deposits in Volcanic Rocks. Proceedings of a Technical Committee Meeting, El Paso, 1984; STI/PUB/690; International Agency of Atomic Energy (IAEA): Vienna, Austria, 1985; pp. 29-51.

68. Burt, D.M.; Sheridan, M.F.; Bikun, J.V.; Christiansen, E.H. Topaz rhyolites-Distribution, origin, and significance for exploration. Econ. Geol. 1982, 77, 1818-1836. [CrossRef]

69. Christiansen, E.H.; Burt, D.M.; Sheridan, M.F.; Wilson, R.T. The petrogenesis of topaz rhyolites from the western United States. Contrib. Mineral. Petrol. 1983, 83, 16-30. [CrossRef]

70. Burt, D.M.; Sheridan, M.F. Types of mineralisation related to fluorine-rich silicic lava flows and domes. Geol. Soc. Am. Spec. Paper 1987, 212, 103-109.

(C) 2019 by the authors. Licensee MDPI, Basel, Switzerland. This article is an open access article distributed under the terms and conditions of the Creative Commons Attribution (CC BY) license (http:/ / creativecommons.org/licenses/by/4.0/). 